
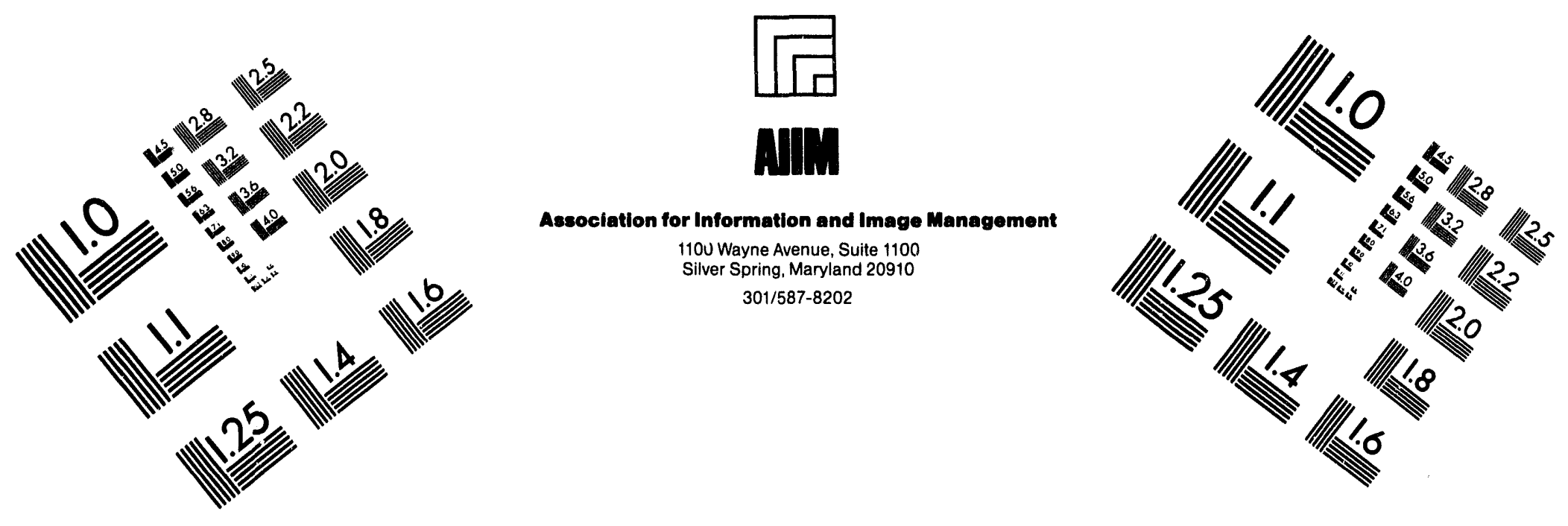

\title{
Centimeter
}

$\begin{array}{llllllllllllllll}1 & 2 & 3 & 4 & 5 & 6 & 7 & 8 & 9 & 10 & 11 & 12 & 13 & 14 & 15 & \mathrm{~mm}\end{array}$

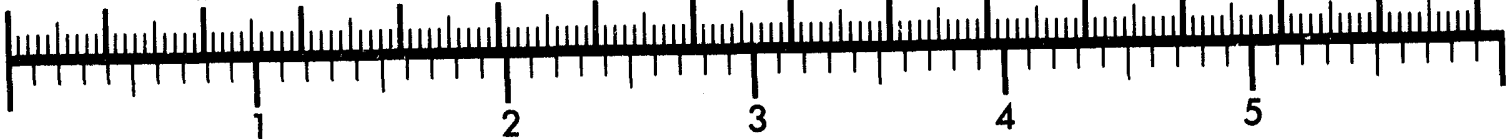
Inches
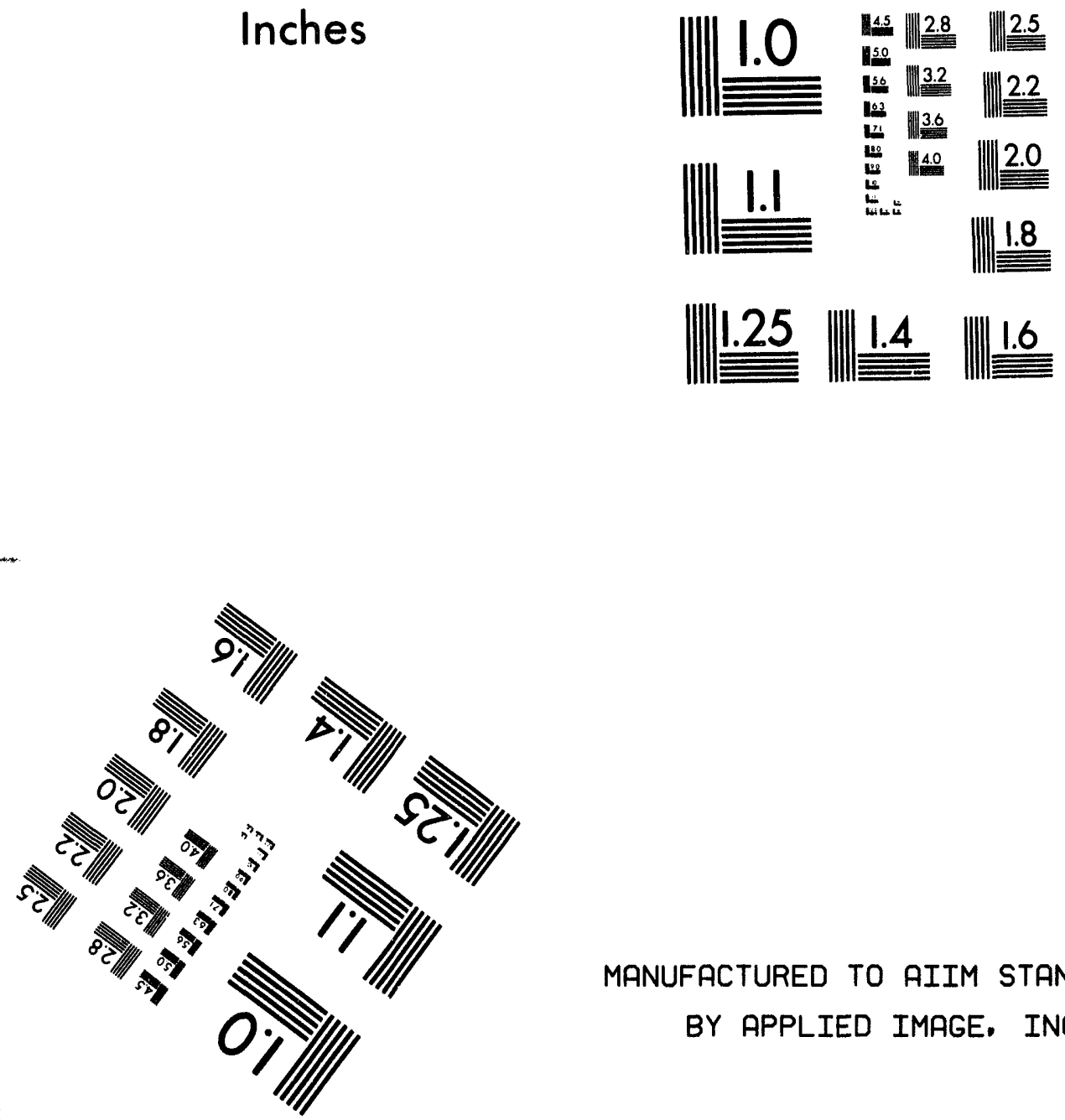

MANUFACTURED TO AIIM STANDARDS BY APPLIED IMAGE, INC.

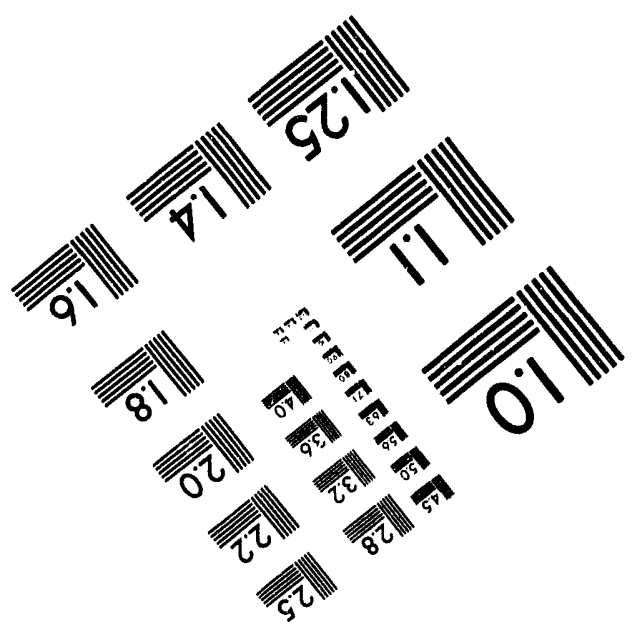



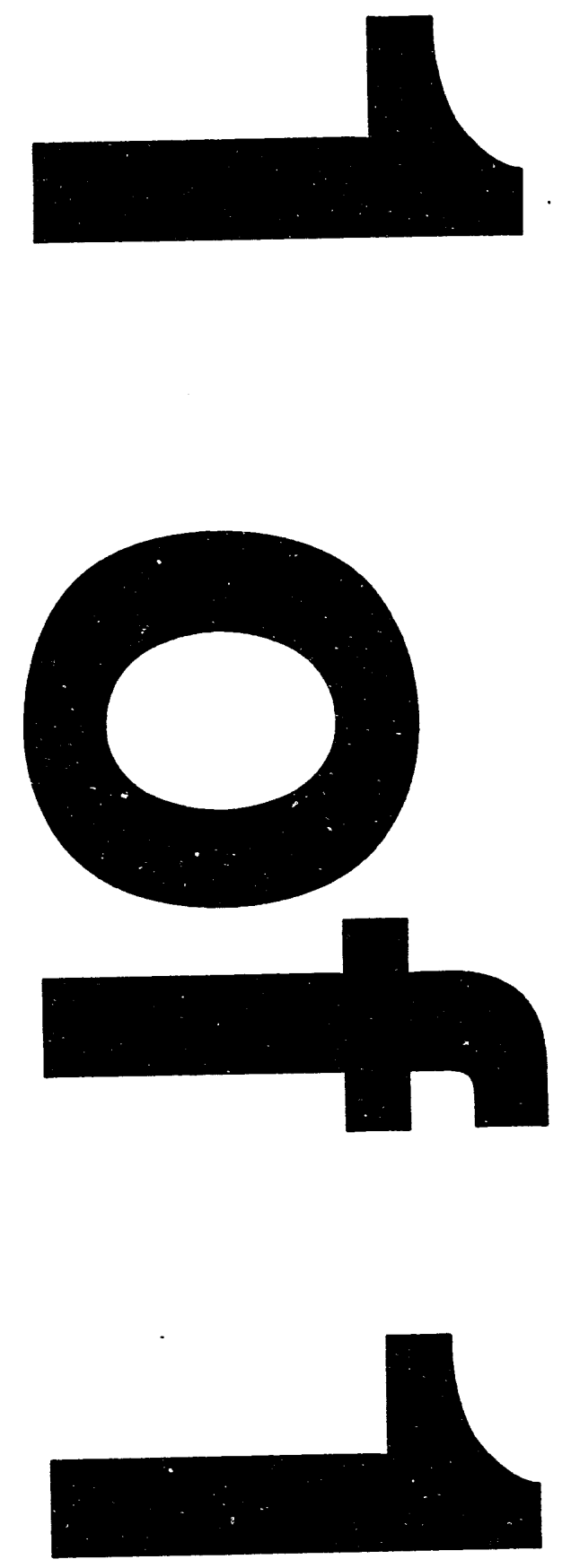


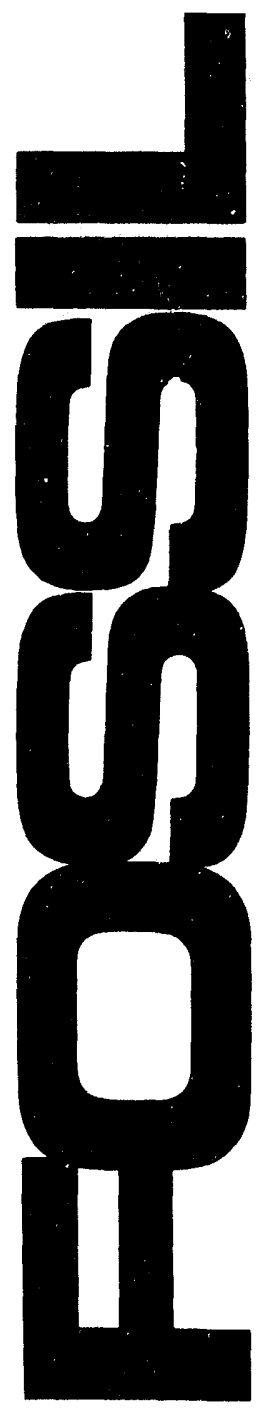

\section{KINETICS OF COAL CONVERSION TO SOLUBLE PRODUCTS}

Final Technical Report

\section{By}

John W. Larsen

February 1994

Work Performed Under Contract No. FG22-87PC79926

For

U.S. Department of Energy

Plttsburgh Energy Technology Center

Plttsburgh, Pennsylvanla

By

Lehigh University

Bethlehem, Pennsylvanla 


\section{DISCLAIMER}

This report was prepared as an account of work sponsored by an agency of the United States Government. Neither the United States Government nor any agency thereof, nor any of their employees, makes any warranty, express or implied, or assumes any legal liability or responsibility for the accuracy, completeness, or usefulness of any information, apparatus, product, or process disclosed, or represents that its use would not infringe privately owned rights. Reference herein to any specific commencial product, process, or service by trade name, trademark, manufacturer, or otherwise does not necessarily constitute or impiy its endorsement, recommendation; or favoring by the United States Government or any agency thereof. The views and opinions of authors expressed herein do not necessarily state or reflect those of the United States Government or any agency thereof.

This report has been reproduced directly from the best available copy.

Available to DOE and DOE contractors from the Office of Scientific and Technical Information, P.O. Box 62, Oak Ridge, TN 37831; prices available from (615) 576-8401.

Available to the public from the U.S. Department of Commerce, Technology Administration, National Technical Information Service, Springfield, VA 22161, (703) 487-4650. 


\title{
Kinetics of Coal Conversion to Soluble Products
}

Final Technical Report

\author{
John W. Larsen \\ Department of Chemistry \\ Lehigh University \\ Bethlehem, Pennsylvariiz 18015 \\ February 1994
}

Prepared for the United State Department of Energy under contract DE-FG22-87PC79926 
INDEX

Coal Conversion........................ I

Conversion Product stability.............. 32

Effect of Added Phenanthrene............. 37

Conversion of Macerals..................43

${ }^{252}$ Cf Plasma Desorption Mass Spectrometry

Molecular Weight Distributions.......... 45

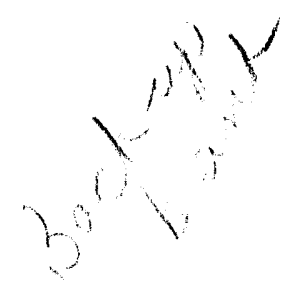


Coal Conversion

For as long as solid coal has been converted to soluble products, the kinetics of the process have been studied. One fundamental analytical approach has nearly universally been used: the rate at which insoluble coal is converted to soluble material. The solubility increase in the solvent of choice has been measured as a function of time, and this solubility increase has been used to determine the kinetics of the coal conversion process. ${ }^{1,2}$ This is adequate for many purposes, but cannot provide a fundamental understanding of the processes occurring, since wne changes being measured are complex and not a direct reflection of the numbers of bonds being broken. The solubility of a coal product in any solvent will depend on both the size of the molecules and their polarity.

The objectives of this work are 1) to measure the kinetics of the conversion of coals to soluble products under model Iiquefaction conditions using GPS techniques to count the number of bonds broken; 2) to analyze these data using kinetic schemes based on the behavior of crosslinked macromolecular networks.

We have built and successfully tested a computer interfaced gel permeation chromatograph with a mass sensitive detector which requires 10 to $20 \mathrm{mg}$ of sample to produce a complete molecular weight distribution. This chromatograph as been calibrated with coal extract fractions whose molecular weights have been individually measured by vapor pressure osometry. This detector output is also verified to be linear in mass over a concentration 
range which exceeds on both ends of the concentration range used for our analysis. ${ }^{3}$ A typical gel permeation chromatogram recorded for this system is shown in Figure $1 \mathrm{~A}$.

The mass detector utilizes light scattering for detection and there is random noise in its output signal. Some mathematical methods for smoothing the noisy spectrum are quite useful in reducing the noise level. We have modified the programs used to analyze our GPC data, achieving a 10-fold noise reduction (Figure 1). Previous1y, we used a "smoothing" program package provided by Macmillan Software as a built-in function in the Ayst system. This is a post-processing method and is not the best way. A better noise reduction technique is to accumulate and average the noise contaminated signal at each sampling point. Fortunately, the $A / D$ converter used in our mass detector system can sample data points 1000 times a second. The re-worked system collects 100 times more points than the old, then averages them to achieve a $\sqrt{100}=10$ fold noise reduction. A computer recorded chromatogram obtained with a new system is shown in Figure $1 \mathrm{~B}$ and compared with earlier data. The $S / N$ ratio was so much improved that the minimum sample weight required to obtain a useful chromatogram was reduced to about $500 \mathrm{ng}$. This sample amount is almost as low as that required by the normal type of RI detector. Use of lower concentration samples may have significant advantages. Association problems observed in concentrated solutions of coal conversion products may be avoided using more dilute samples. Association and dissociation of coal molecules 
can also be studied by varying the concentration of samples. High resolution chromatograms can be obtained without the danger of overloading the column.

Between the mass detector and the columns, a digital thermal pulse flow meter accurate to $\pm 0.05 \%$ was inserted. The output from the flow meter was also directed to an $A / D$ converter. The flow rate was averaged and integrated to calculate the elution volume at each sampling point. Now we obtain mass detector output as a function of exact elution volume instead of time.

I11. No. 6 coal was processed as shown in Scheme 1 . Liquefaction of I1I. No. 6 coal was achieved in tubing bombs using tetralin as a hydrogen donor solvent at $400^{\circ} \mathrm{C}$. Rapid heating was attained by plunging the reactor into a hot sand bath where it was shaken at 120 cycles per minute for 20 minutes and cooled in air after withdrawal from the sand bath. The product was Soxhlet extracted with pyridine until the pyricine solution was clear. A gel permeation chromatogram of the pyridine soluble is shown in Figure 2A. The improved mass sensitive detector system requires only about $500 \mathrm{ng}$ to acquire a chromatogram having fairly good $\mathrm{S} / \mathrm{N}$ ratio. Apparently, no disturbance is caused by the remaining tetralin and naphthalene formed by dehydrogenation of tetralin. These seriously affect the lower molecular weight region when IR or UV detectors are used. It is a notable advantage of the mass sensitive detector that suitable adjustment of the nebulizer and of the evaporator completely suppressed the contribution of solvent to the chromatogram. The molecular weight distribution of 


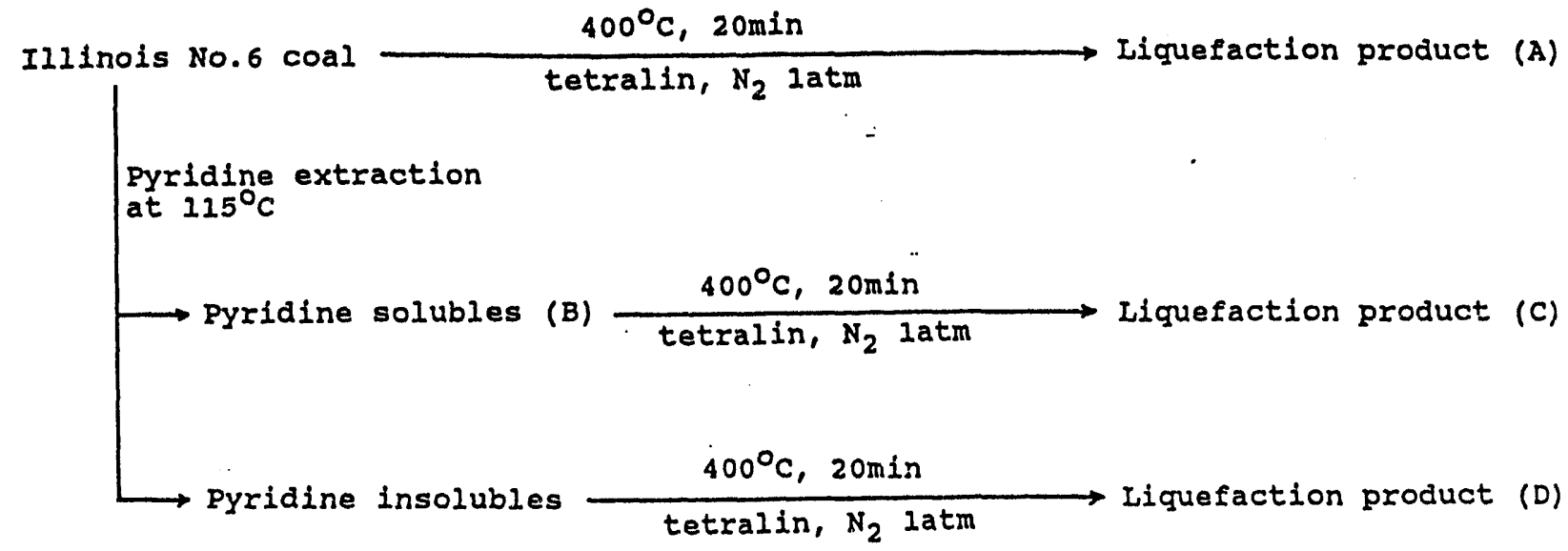

Scheme 1 Procedure for extraction and liquefaction of Illinois No.6 coal
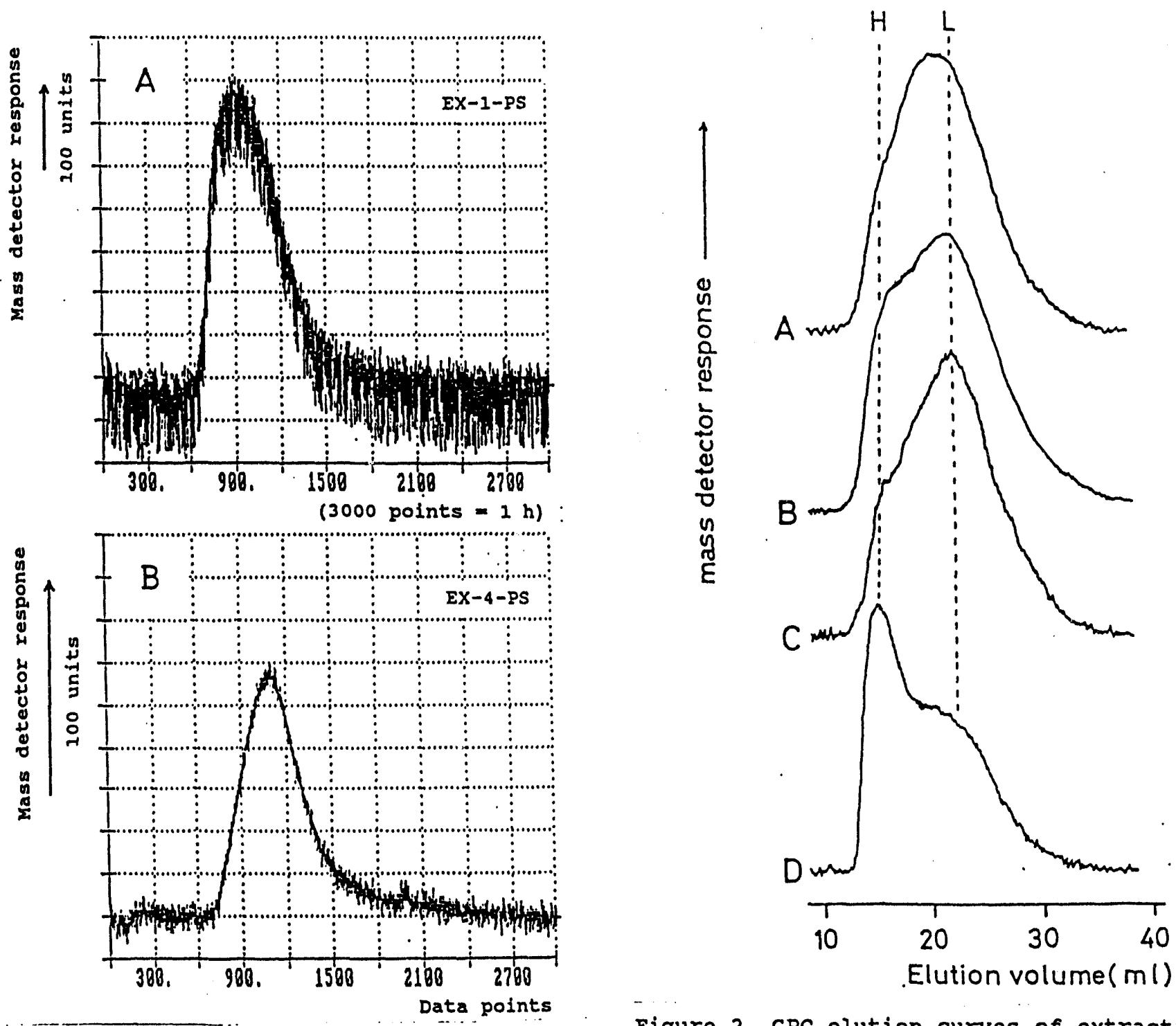

Figure 2 GPC elution curves of extraction and/or liquefaction products from Illinois No. 6 coal ( $A-D$ indicates the corresponding

Figure 1 computer recorded GPC curves

A) without averaging

B) with 100 times averaging products in scheme 1 ) 
liquefaction product appears to be almost unimodal if the small shoulder at the lower elution volume side is neglected.

I11. No. 6 coal was extracted with pyridine for one week. Both the insoluble and soluble portions were dried under vacuum and served as raw materials for the liquefaction reaction. The conditions are the same as mentioned above.

Also shown in Figure 2 are gel permeation chromatograms of the pyridine extract (B), its liquefaction product ( $C$ ), and the liquefaction product from the pyridine insoluble part (D) of the coal. The molecular weight distribution curve seems to be divided into two parts. One is represented by a peak molecular weight of 30,000 (H) and another by 1,100 (L). the pyridine insoluble portion mainly produces higher molecular weight material during liquefaction. All of the soluble material produced is considered to have come from network decomposition. At the same time, it is observed that the higher molecular weight part depolyermizes to lower molecular weight species. Some routine quantitative techniques such as curve fitting will be applied in order to analyze the data further.

Note that the molecular weights given here are relative. The columns require re-calibration and possibly replacement. The gel permeation chromatograph equipped with a mass sensitive detector and with an improved data acquisition system has proven to be a powerful tool for measuring the change in molecular weight distribution during the coal depolymerization process. Using this system, we will monitor the kinetics of coal 
conversion under various conditions, by measuring the molecular weight distribution of the soluble products as a function of time. The kinetic data will be analyzed using standard polymer chemistry approaches. 4

The insoluble portion of the coal is best treated as a crosslinked network system. The kinetic data will be fit to the expressions derived by Yan for lignin depolymerization. ${ }^{5-9}$

This chromatograph system was equipped with three waters $\mu$-styragel $\left(10^{3}+500+100\right.$ A) columns. Exclusion limit is, however, considered to be lower than required for the samples. Furthermore, build-up of operating pressure anci a decrease in the retention volume of standard samples was observed. We have replaced these old columns with four new $\mu$-styragel $\left(10^{4}+10^{3}+\right.$ $500+100$ \&) columns, providing superior resolution enhancement.

Pyridine is supposed to be an ideal mobile phase to study the nature of coal derived Iiquids and is our chosen solvent. 3,10 Careful operation is required to maintain high resolution GPC columns. Changes in the resolution and/or retention volume of a standard polystyrene sample injected into the new columns were checked. There was no increase in back pressure nor change in retention volume of the polystyrene standards after running for over 200 hrs.

The liquefaction of Illinois No. 6 coal (A) was achieved in tubing bombs using tetralin as the hydrogen donor solvent at 400 and $425^{\circ} \mathrm{C}$. Illinois No. 6 coal had been dried at $110^{\circ} \mathrm{C}$ under vacuum to constant weight and had been stored under nitrogen 
atmosphere. Rapid heating was attained by plunging the reactor into a pre-heated sand bath where it was shaken at 120-180 cycles per minute and cooled in air after withdrawal from the sand bath. The product was soxhlet-extracted with pyridine until the pyridine solution was clear.

Illinois No. 6 coal was extracted with pyridine for one week. Both the insoluble (B) and soluble (C) portions were dried under vacuum and served as raw materials for the liquefaction reactions. The conditions are the same as mentioned above.

Conversions of $A, B$, and $C$ into pyridine-soluble materials were more than 92, 90, and 99\% (d.a.f. basis), respectively. In Figure 3, GPC elution curves of liquefaction products at $400^{\circ} \mathrm{C}$ are shown as a function of reaction time. Bimodal elution curves were obtained. The higher molecular weight peak appeared at an elution volume of 20-30 $\mathrm{ml}$ in a short reaction time of $A$ and $B$. An unexpectedly low molecular weight peak was also observed. Higher molecular weight materials, especially those eluting at around 23 $\mathrm{ml}$, react, forming lower molecular weight materials. A similar tendency was observed with the liquefaction products of $c$, although the relative quantity of the higher molecular weight materials was small.

In random depolymerization of crosslinked macromolecular networks, the product molecular weight increases with the extent of reaction. The product molecular weight distribution is expected to be unimodal and peak in the lower molecular weight region. The results obtained here indicate that coal depolymerization involves considerably more complicated reaction paths and non-uniform bond cleavage. $7-9,11$ 


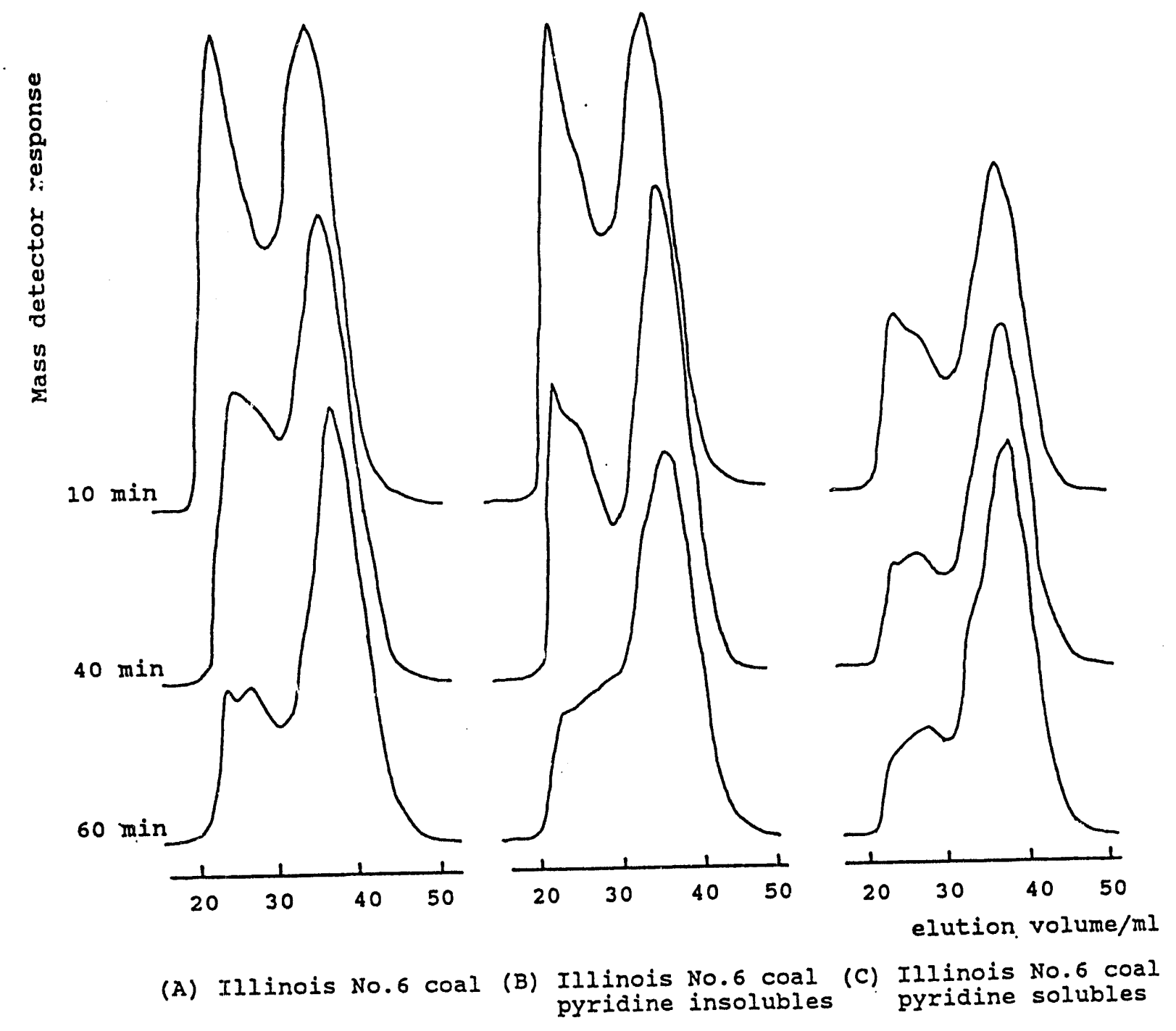

Figure 3. GPC elution curves of $400^{\circ} \mathrm{C}$ liquefaction products 

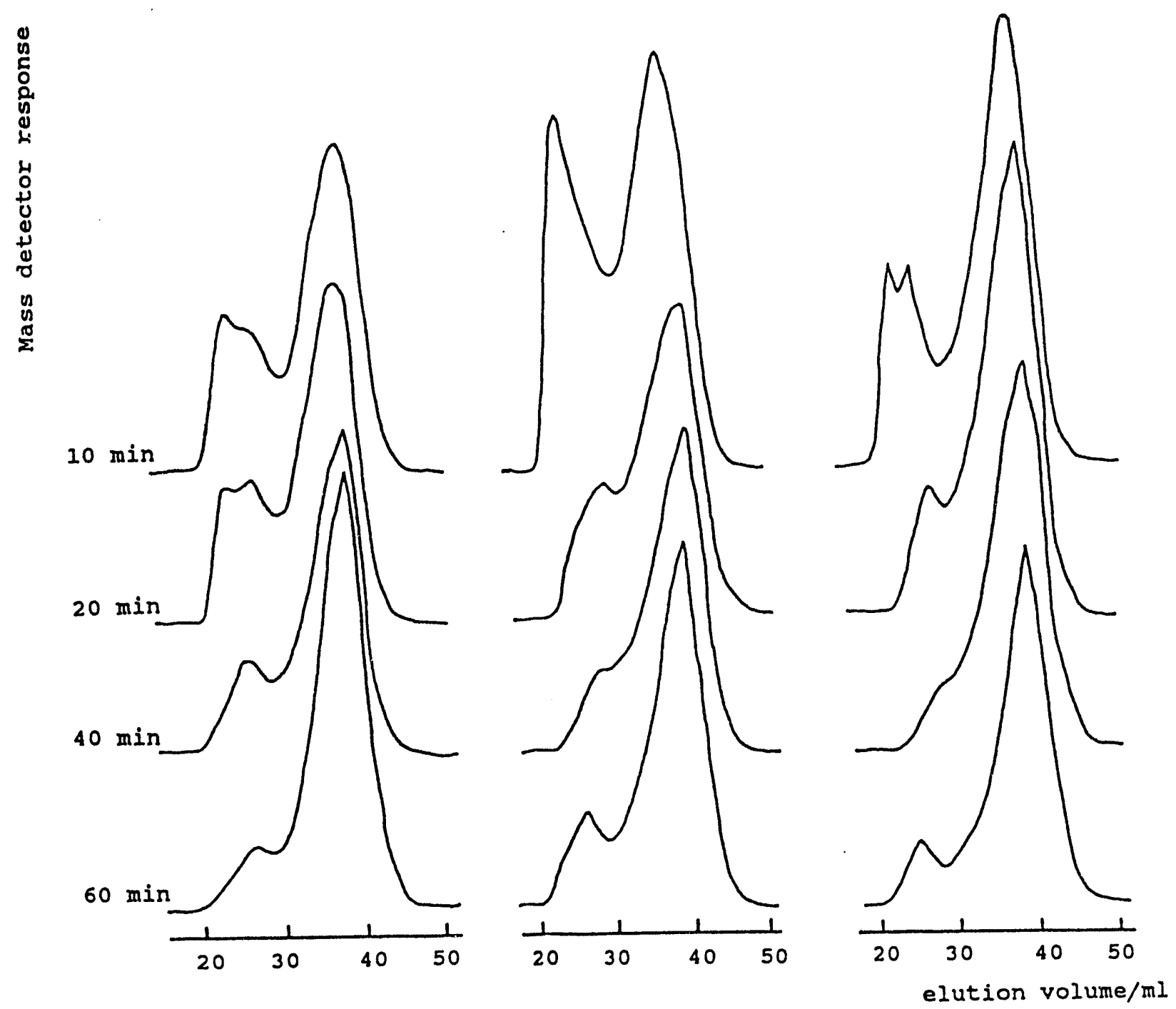

(A) Illinois No.6 coal

(B) Illinois No.6 coal pyridine insolubles
(C) Illinois No.6 coal pyridine solubles

Figure 4. GPC elution curves of $425^{\circ} \mathrm{C}$ liquefaction products 
In Figure 4, GPC elution curves of $425^{\circ} \mathrm{C}$ liquefaction products are shown. Bimodal molecular weight distributions were obtained. At the high temperature, there was less high molecular weight material and it depolymerized faster. After $40 \mathrm{~min}$, the higher molecular weight peaks almost disappeared. However, an increase in the high molecular weight peak was observed after 60 min. of reaction time with $B$ and $C$. This GPC chromatogram clearly shows that prolonged reaction time allows more retrogressive reactions which form larger molecules.

Liquefaction experiments were run with Illinois No. 6 coal and were run separately on its pyridine insoluble and soluble portions. Can the product molecular weight distributions obtained with the pyridine extract and residue be added to generate the molecular weight distribution of the whole coal? Does removing the pyridine extract alter reactivity? The peak areas of the GPC elution curves for Illinois No. 6 coal, its pyridine extract and residue were normalized to $100 \%$ (respectively, $S_{I I}, S_{P I}$, and $S_{P S}$ ). $S_{P I}$ and $S_{P S}$ were multiplied by the factors derived from the pyridine extraction yield of Illinois No. $6 \operatorname{coal}\left(c_{x}\right)$ and liquefaction yields $\left(C_{P I}\right.$ and $\left.C_{P S}\right)$, then added to each other to generate a theoretical molecular weight distribution for whole coal products (see below):$$
s_{C A I}=s_{P I} \cdot\left(1-c_{x}\right) \cdot c_{P I}+s_{P S} \cdot c_{x} \cdot c_{\underline{P S}}
$$$$
\text { where } S_{I I}=S P I=S_{P S} \text {. }
$$ 


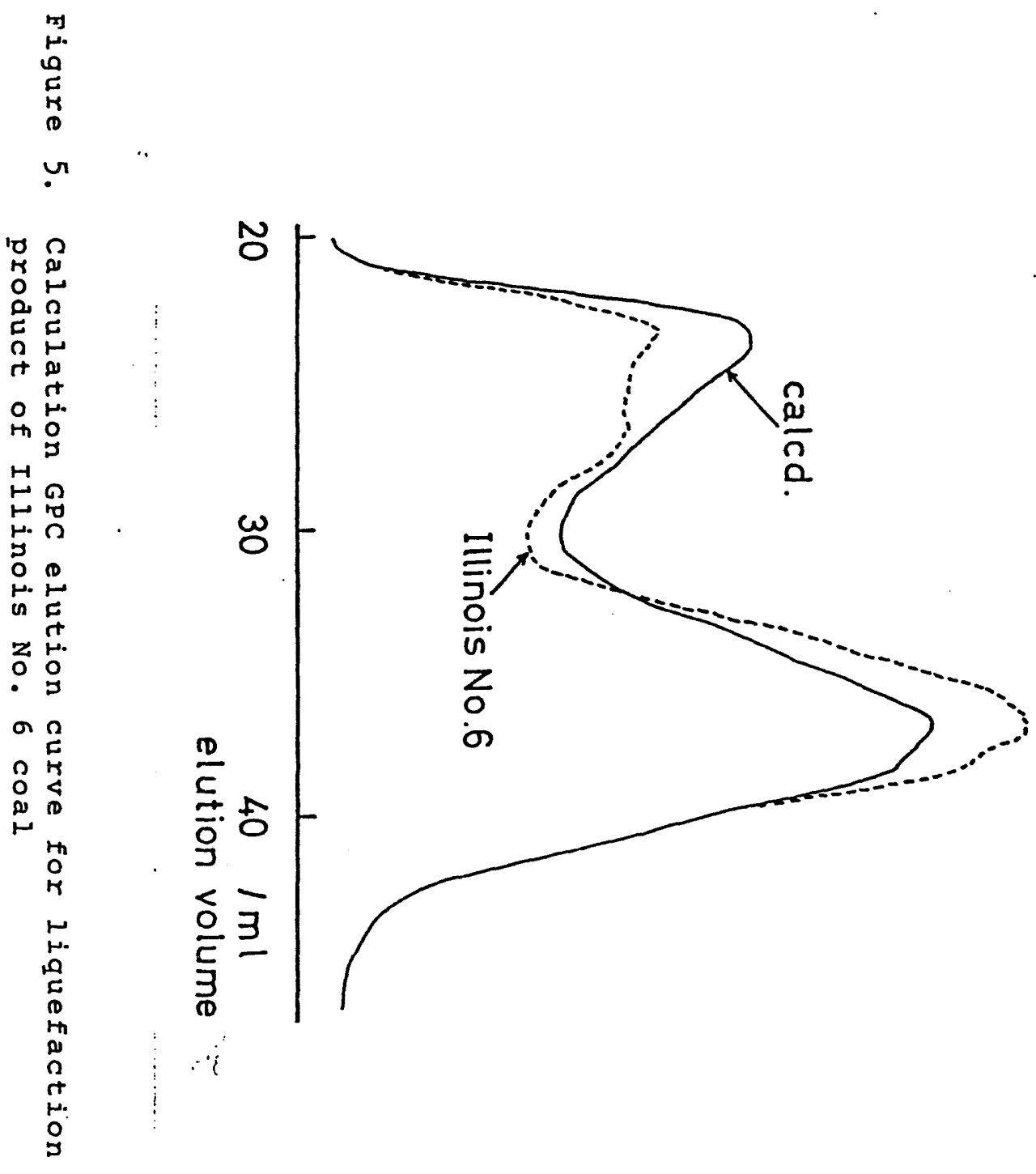


The result is shown in Figure 5. In this case, $c_{x}=0.31, c_{p l}=$ 1, and $C_{p s}=1$. There is a discrepancy between the calculated curve and that observed for the Illinois No. 6 coal. The higher molecular weight region of the calculated curve (solid line) is larger than that observed (dotted line).

To provide more reliable molecular weights for the coal products, additional calibration of the columns was carried out. In addition to using standard polystyrene, polynuclear aromatic compounds and coal-derived materials having relatively narrow symmetric molecular weight distributions $\left(\overline{\mathrm{M}}_{\mathrm{w}} / \overline{\mathrm{M}}_{\mathrm{n}}<1.9\right)$ were used. Standard samples from coal were prepared by fractionation of pyridine extracts of Iilinois No. 6 coal and were chosen from fractionated materials of liquefied Kentucky coal. ${ }^{3}$ A pyridine solution of coal-derived materials was filtered using a Millipore $0.2 \mathrm{um}$ sample clarification filter. The clarified solutions were used for gel permeation chromatography and vapor pressure osmometry to measure the peak position and the number-average molecular weight. It was difficult to get standard samples having symmetric narrow molecular weight distributions by fractionated of pyridine extracts due to the low resolution of the preparation column we used, although materials with $\overline{M_{w}} / \overline{M_{n}}<1.2$ are generally recommended for calibration of GPC columns.5 Sample solutions were dried at $110^{\circ} \mathrm{C}$ under vacuum to constant weight to determine the concentration. The calibration curve obtained is shown in Figure 6. A calibration curve obtained by standard polystyrene and model compounds seems to be reasonable. 
In the low elution volume region, the molecular weight measured by VPo for the fractionated sample deviated greatly from the polystyrene calibrated curve.

\section{Liquefaction experiments were run using tetralin and coal} (Illinois No. 8 or Pittsburgh No. 8), and separately with its pyridine-insoluble (PI) and pyridine-soluble portions (PS). As reported in a previous quarterly report, conversions of coal, coal extracts, and extraction residue were high at $400-425^{\circ} \mathrm{C}$ with reaction times between 10 and $60 \mathrm{~min}$. Milder conditions were used to slow down the reactions to make the kinetic experiments easier.

Coals were dried at $110^{\circ} \mathrm{C}$ under vacuum to constant weight and were stored under dry nitrogen. Coals were extracted with pyridine for one week. Both the insoluble and soluble portions were dried and stored in the same manner as the coals. Liquefaction experiments were carried out using three tubing bombs separately. These tubing bombs contained coal, its pyridine insolubles and its soluble portion under the same conditions (tetralin solvent, 1 etm of nitrogen atmosphere, at $350^{\circ} \mathrm{C}$ or $375^{\circ} \mathrm{C}$ for $\left.1-20 \mathrm{~min}\right)$. Rapid heating was attained by plunging the reactions into a preheated sandbath. The bombs were shaken at 200-250 cycles per minute. The time-temperature profile was measured by using a thermocouple inserted directly into the 


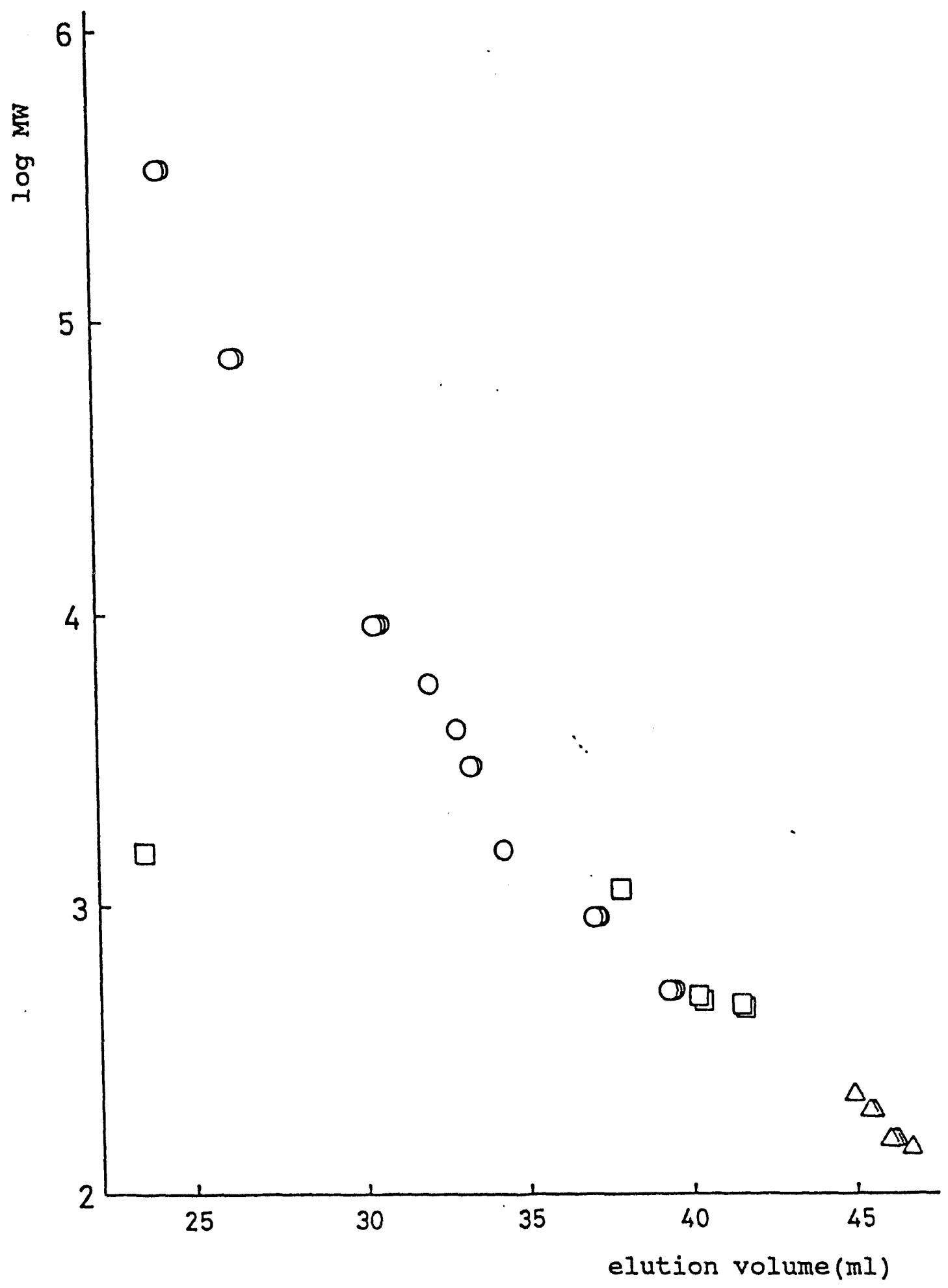

Figure 6: Calibration curve for $\mu$-styragel columns obtained by polystyrene $(O)$, polynuclear aromatic compounds $(\Delta)$, and coal-derived materials $(\square)$ with pyridine as a mobile phase. 


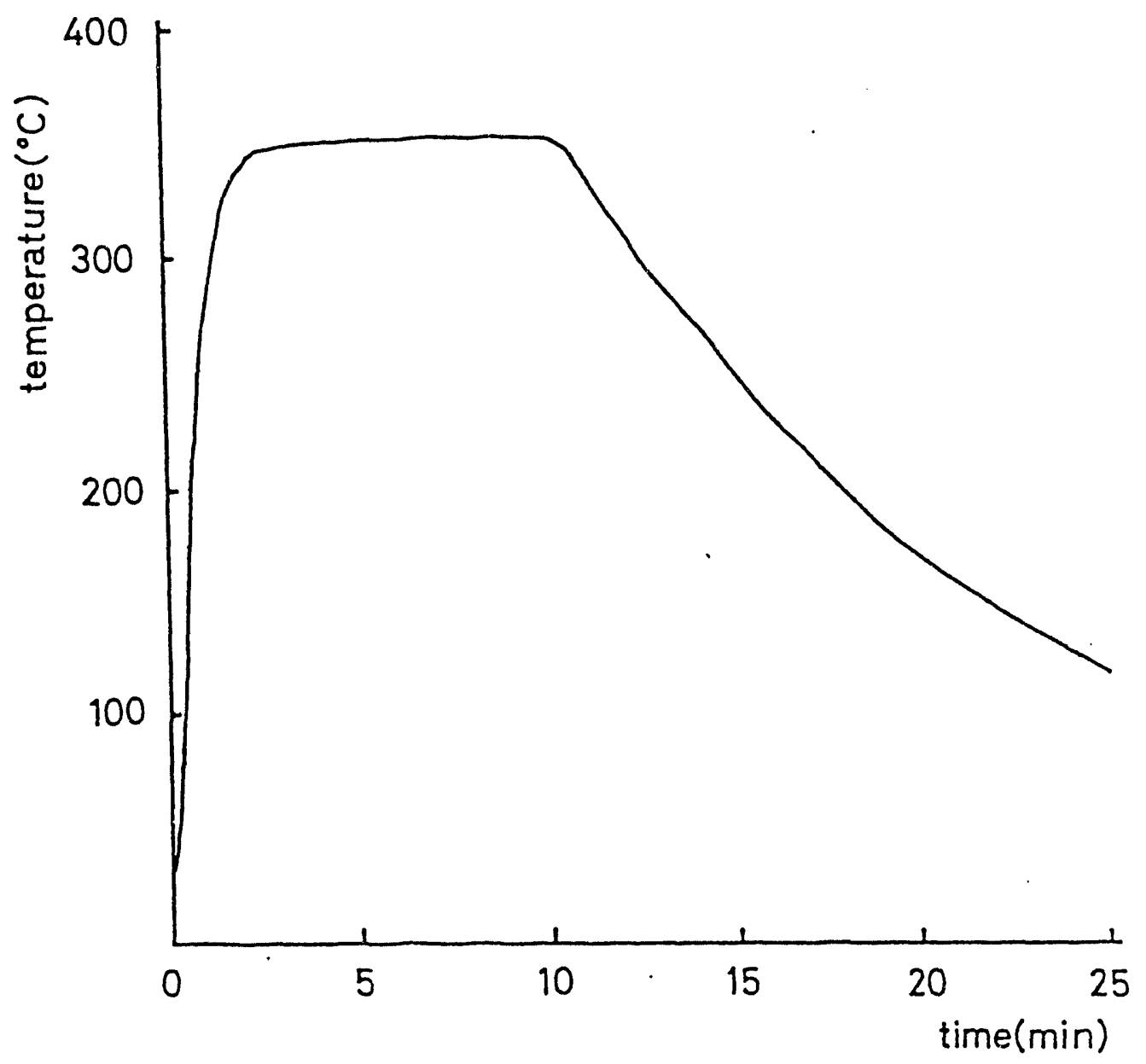

Figure 7. Typical time-temperature profile of a tubing reactor. 
reaction mixture as shown in Figure.7. It took 80-90 seconds to reach a temperature which was $25^{\circ} \mathrm{C}$ below the nominal reaction temperature. The reactors were air cooled after they were withdrawn from the sandbath. The products were Soxhlet extracted with pyridine under a nitrogen atmosphere until the solvent was clear, then they were analyzed by GPC just after termination of the extraction.

The results are summarized in Table 1 . The conversions of Illinois No. 6 coal and its pyridine-soluble portion at $375^{\circ} \mathrm{C}$ for 10-20 min are still high. Even the pyridine-insoluble part gave more than $60 \%$ conversion in $10 \mathrm{~min}$. When the reaction temperature was lowered to $350^{\circ} \mathrm{C}$, the conversion rate of coal and pyridine insolubles was considerably lower, as expected. The decrease in the conversion of pyridine insolubles was remarkable.

A similar tendency was observed with Pittsburgh No. 8 coal. Conversion of the pyridine solubles was higher than with the Illinois No. 6 coal solubles. Coals retain pyridine and it was necessary to determine whether this retained pyridine played any role in the depolymerization reaction. Liquefaction reactions were run at $375^{\circ} \mathrm{C}$ for 5 min using Pittsburgh No. 8 coal in tetralin with and without added pyridine. Also, pyridine was added to the coal ( $10 \%$ weight) and also deposited in the coal from the vapor state for 14 days. There was very little difference between the liquefaction yields of the various pyridine-containing coals. Pyridine has little or no effect on the liquefaction yield and molecular weight distribution of the resulting products. 
Table 1 Results of liquefaction reactions in tetralin ${ }^{a}$

run coal temp time conversions $^{\mathrm{b}}$ into pyridine solubles and MWDs of products ${ }^{\mathrm{d}}$

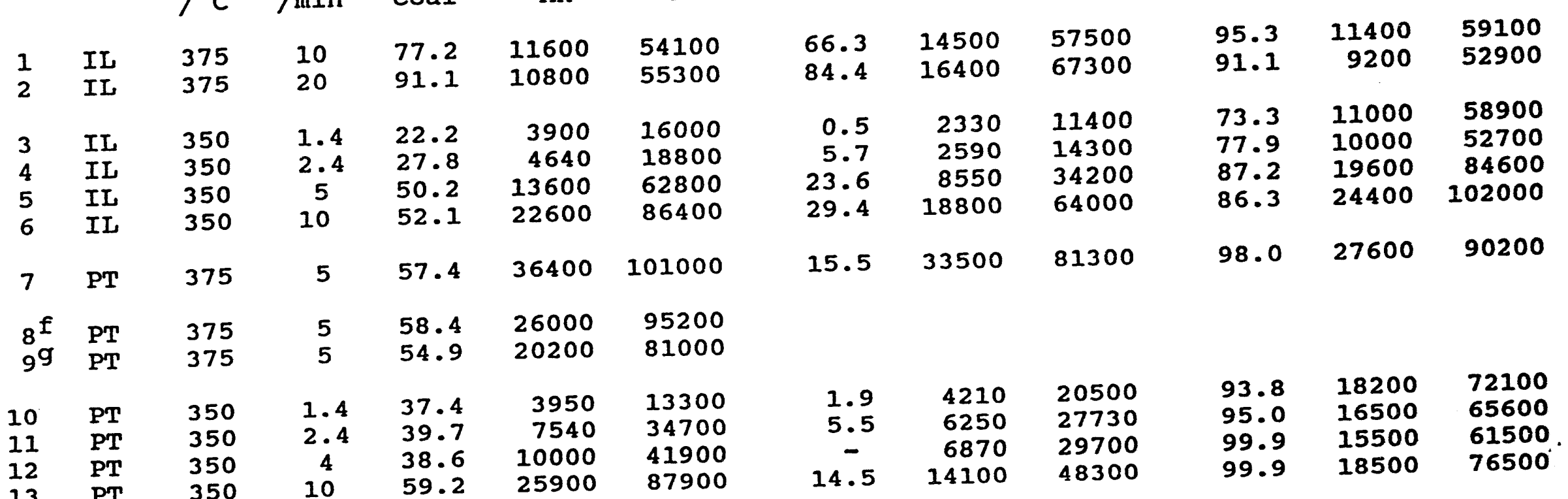

a) $1-2 \mathrm{~g}$ of coal, its pyridine insoluble part(PI), or its pyridine soluble part(PS) was uesd a raw material, raw material/tetralin $=1 / 2(\mathrm{w} / \mathrm{w})$, under nitrogen atmosphere ( 1 atm, cold). b) IL: Illinois No.6 coal, Argonre premium coal sample, PT: Pittsburgh No.8 coal, Argonne

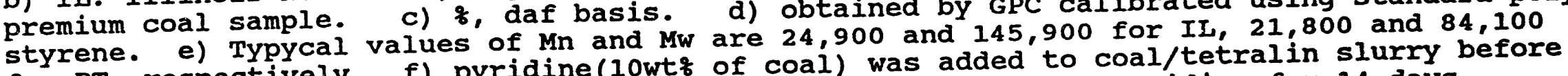

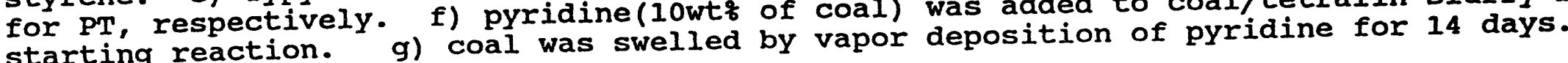


The changes in the molecular weights of liquefaction products obtained from pyridine solubles are complicated. The molecular weight was decreased at a very early stage of liquefaction, then increased again after 2-4 min for both Illinois No. 6 and Pittsburgh No. 8 coals. This indicates that depolymerization and retrogressive reactions took place under such mild liqiuefaction conditions.

The GPC elution curves of the liquefaction products from Illinois No. 6 and Pittsburgh No. 8 coals are shown in Figures 8 and 9 , respectively. The molecular weight scale is calibrated against standard polystyrene. All the liquefaction products obtained show a similar tendency in GPC elution curves. Shoulder peaks appear at high molecular weight and increase with the increase in reaction time. The main low molecular weight peak shows no obvious change. The high molecular weight peak could involve some highly polar materials having lower molecular weight. 12,13 However, the conversion process should be removing these by hydrogenation and deoxygenation. To elucidate the exact molecular weight changes, factors such as the contribution of polar materials to the high molecular weight must be estimated.

The increase in the molecular weight of the liquefaction products from the pyridine solubles with increasing reaction time is of great interest. We previously reported the increase in the high molecular weight peak when the reaction time was increased from 40 to $60 \mathrm{~min}$ at $425^{\circ} \mathrm{C}$ in tetralin. Both of these results may be a direct observation of "retrogressive reactions" in coal 


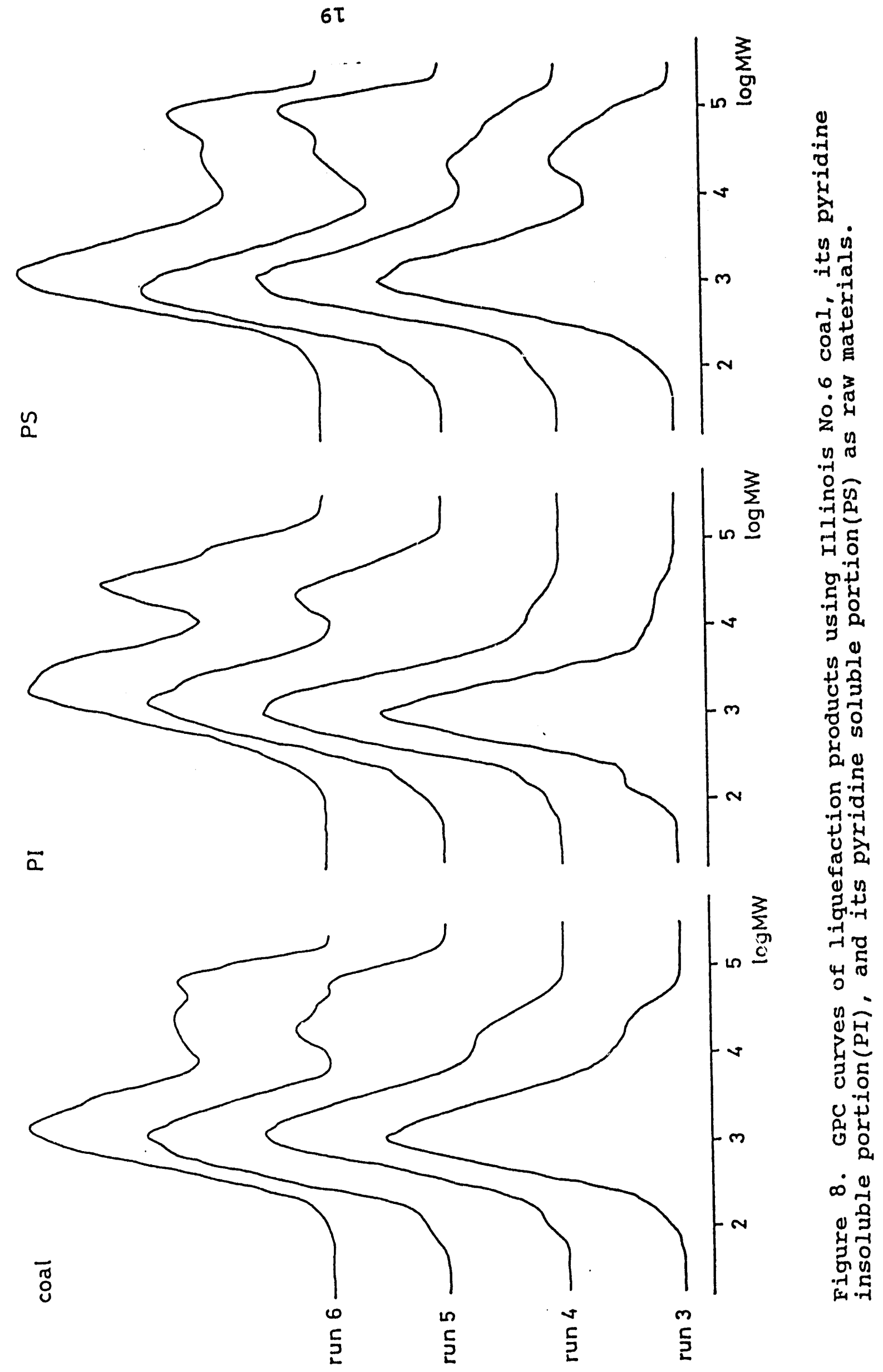



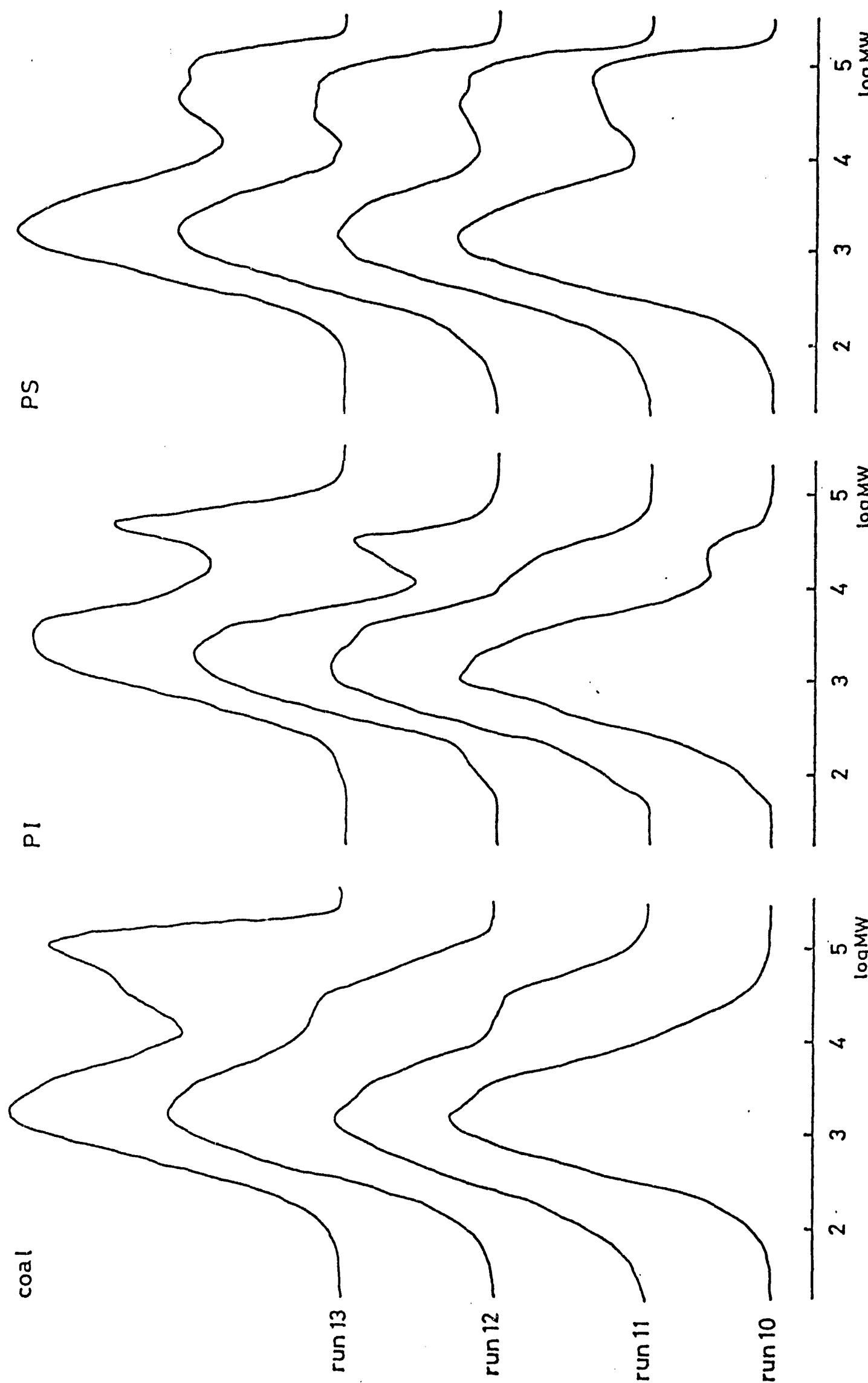

asuodsad dojJałap ssew 
liquefaction using tetralin, one occurring under mild conditions and the other under severe conditions.

since hydrogen is transferred from tetralin to coal, hydrogen consumption during conversion can be obtained by measuring the tetralin-to-naphthalene conversion as obtained by Gas chromatography (GC). A Hewlett Packard Model 5890 instrument with a thermal conductivity detector was used with a $2 \mathrm{~m}$ stainless steel column packed with $20 \%$ OV-351 on Chromosorb WHP $80 / 100$ mesh. For each experiment, the running conditions of GC are: 1) carrier gas and flow rate: He (10ml/min); 2) oven temperature: $180^{\circ} \mathrm{C}$; 3) injection port temperature: $300^{\circ} \mathrm{C}$; 4) detector temperature: $250^{\circ} \mathrm{C} ;$ and 5) final time for each run: $10 \mathrm{~min}$.

Table 2 gives the results of the coal conversion reactions and Table 3 shows the weight percent of hydrogen consumption for liquefaction products on a dry ash-free basis.

The molecular weight of the liquefaction products will be measured by VPO. For this purpose, the VPO has been calibrated using benzil. Poly ( $\delta$-methyl styrene) with a peak molecular weight of $M_{p}=4700$, has been chosen as an unknown. The number average molecular weight measured $M_{n}=4741$, indicating that the low molecular weight determination of liquefaction products can be measured by VPo. 
Table 2. Liquefaction Results

\begin{tabular}{|c|c|c|c|c|c|}
\hline Sample & $\begin{array}{l}\text { Temp. } \\
\left({ }^{\circ} \mathrm{C}\right)\end{array}$ & $\begin{array}{l}\text { Time } \\
(\min )\end{array}$ & $\begin{array}{c}\text { Liquefaction } \\
\text { Yield } \\
(\text { daf } 7)\end{array}$ & $M_{n}$ & ${ }^{M_{W}}$ \\
\hline $\begin{array}{l}I L^{a} \\
I L-P S^{b} \\
I L-P I^{c}\end{array}$ & $\begin{array}{l}350 \\
350 \\
350\end{array}$ & $\begin{array}{l}20 \\
20 \\
20\end{array}$ & $\begin{array}{l}75.5 \\
99.9 \\
48.5\end{array}$ & $\begin{array}{r}12500 \\
7095 \\
10500\end{array}$ & $\begin{array}{l}54200 \\
40260 \\
41400\end{array}$ \\
\hline $\begin{array}{l}\text { IL } \\
\text { IL-PS } \\
\text { IL-PI }\end{array}$ & $\begin{array}{l}350 \\
350 \\
350\end{array}$ & $\begin{array}{l}40 \\
40 \\
40\end{array}$ & $\begin{array}{l}90.1 \\
99.9 \\
57.9\end{array}$ & $\begin{array}{l}16500 \\
12100 \\
11400\end{array}$ & $\begin{array}{l}74300 \\
61200 \\
57100\end{array}$ \\
\hline $\begin{array}{l}P T^{d} \\
P T-P S \\
P T-P I\end{array}$ & $\begin{array}{l}350 \\
350 \\
350\end{array}$ & $\begin{array}{l}10 \\
10 \\
10\end{array}$ & $\begin{array}{l}50.2 \\
87.8 \\
21.4\end{array}$ & $\begin{array}{r}13600 \\
17300 \\
8550\end{array}$ & $\begin{array}{l}52900 \\
68100 \\
31600\end{array}$ \\
\hline
\end{tabular}

al: Illinois No. 6 coal, Argonne premium coal sample

$b_{P S}$ : Pyridine-soluble part of coal

${ }^{c}$ PI: Pyridine-insoluble part of coal

$\mathrm{d}_{\mathrm{PT}}$ : Pittsburgh No. 8 coal, Argonne premium coal sample 
Table 3. Hydrogen Consumption of Liquefaction Products

Sample Temperature Reaction Time Hydrogen Consumption Wt\% daf (q) (min) $\quad$ Coal $\quad P S^{a} \quad P I^{b}$

\begin{tabular}{|c|c|c|c|c|c|}
\hline $\begin{array}{l}\text { IL } \\
\text { IL } \\
\text { IL } \\
\text { IL } \\
\text { IL }\end{array}$ & $\begin{array}{l}425 \\
425 \\
425 \\
425 \\
425\end{array}$ & $\begin{array}{l}10 \\
20 \\
40 \\
60 \\
80\end{array}$ & $\begin{array}{l}0.929 \\
1.413 \\
1.665 \\
2.815 \\
3.333\end{array}$ & $\begin{array}{l}0.883 \\
1.491 \\
1.339 \\
2.505 \\
2.799\end{array}$ & $\begin{array}{l}1.008 \\
1.459 \\
2.512 \\
3.224 \\
3.646\end{array}$ \\
\hline $\begin{array}{l}\text { IL } \\
\text { IL } \\
\text { IL } \\
\text { IL }\end{array}$ & $\begin{array}{l}400 \\
400 \\
400 \\
400\end{array}$ & $\begin{array}{l}10 \\
20 \\
40 \\
60\end{array}$ & $\begin{array}{l}0.899 \\
1.101 \\
1.669 \\
1.565\end{array}$ & $\begin{array}{l}0.808 \\
1.035 \\
1.429 \\
1.607\end{array}$ & $\begin{array}{l}0.961 \\
1.261 \\
1.785 \\
1.713\end{array}$ \\
\hline $\begin{array}{l}\text { IL } \\
\text { IL } \\
\text { IL } \\
\text { IL } \\
\text { IL } \\
\text { IL } \\
\text { IL . } \\
\text { IL }\end{array}$ & $\begin{array}{l}375 \\
375 \\
350 \\
350 \\
350 \\
350 \\
350 \\
350\end{array}$ & $\begin{array}{r}10 \\
20 \\
15 \\
25 \\
5 \\
10 \\
20 \\
40\end{array}$ & $\begin{array}{l}0.366 \\
0.599 \\
0.031 \\
0.063 \\
0.146 \\
0.198 \\
0.229 \\
0.368\end{array}$ & $\begin{array}{l}0.332 \\
0.546 \\
0.035 \\
0.071 \\
0.221 \\
0.288 \\
0.234 \\
0.452\end{array}$ & $\begin{array}{l}0.440 \\
0.637 \\
0.769 \\
0.133 \\
0.200 \\
0.258 \\
0.396 \\
0.587\end{array}$ \\
\hline $\begin{array}{l}\mathrm{PT}^{\mathrm{d}} \\
\mathrm{PT} \\
\mathrm{PT} \\
\mathrm{PT}\end{array}$ & $\begin{array}{l}350 \\
350 \\
350 \\
350\end{array}$ & $\begin{array}{l}1.4 \\
2.4 \\
4 \\
10\end{array}$ & $\begin{array}{l}0.021 \\
0.025 \\
0.035 \\
0.054\end{array}$ & $\begin{array}{l}0.021 \\
0.024 \\
0.044 \\
0.081\end{array}$ & $\begin{array}{l}0.027 \\
0.041 \\
0.068 \\
0.112\end{array}$ \\
\hline
\end{tabular}

aps: Pyridine-soluble part of coal

$b_{P I}$ : Pyridine-insoluble part of coal

CIL: Illinois No. 6 coal, Argonne premium coal sample

$d_{\mathrm{PT}}$ : Pittsburgh No. 8 coal, Argonne premium coal sample 
We had earlier obtained evidence for the existence of retrogressive reactions even at low temperatures during coal conversion. To further explore this issue, the behavior of the soluble pyridine coal extracts was studied.

The number average $\left(\bar{M}_{n}\right)$ and weight average $\left(\bar{M}_{W}\right)$ molecular weight data obtained for the first series of experiments using pyridine extracts from Illinois No.6 coal as the substrate are collected in Table 4. The first entry in the table gives the molecular weights of the coal extract used as a substrate for liquefaction. In all cases the liquefaction products were pyridine soluble and the molecular weights of the products were higher than the starting material. This is an important observation, demonstrating that even in the presence of a good hydrogen donor

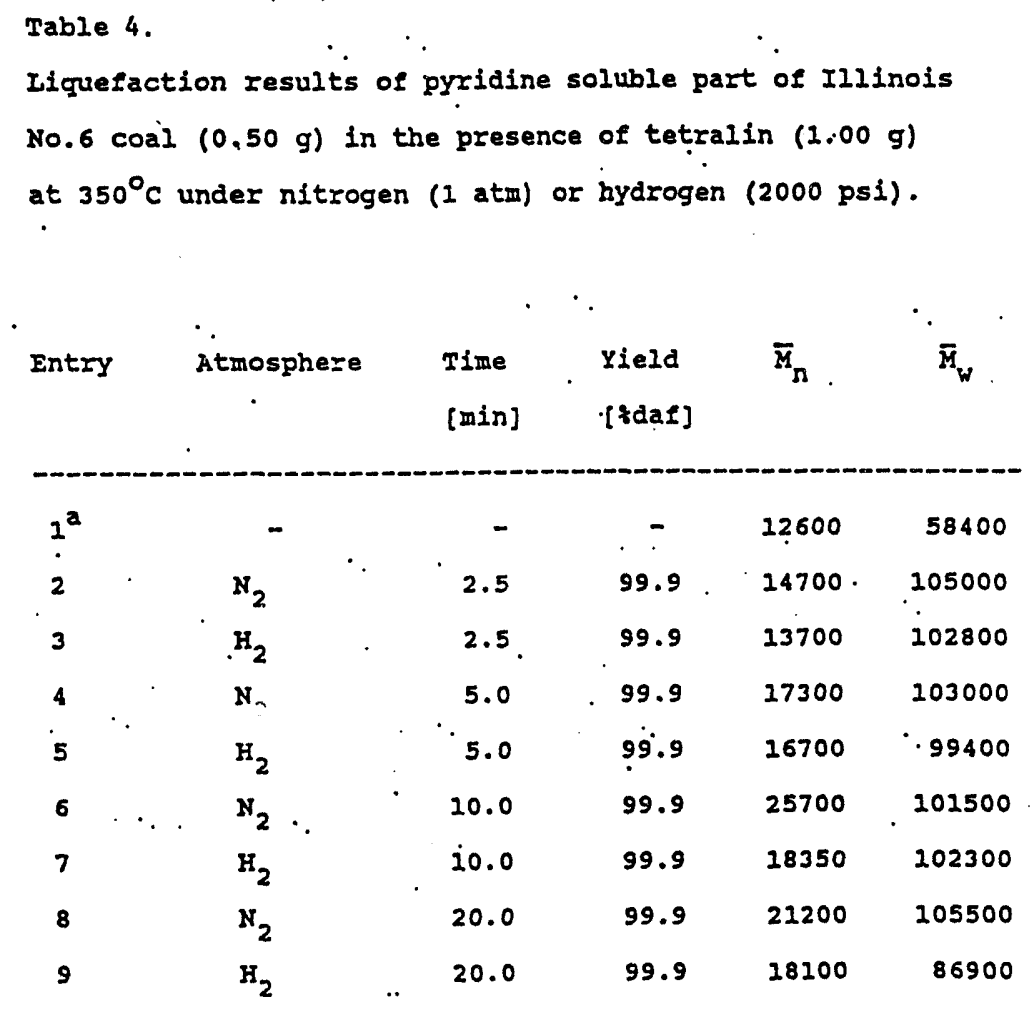


solvent such as tetralin, coupling of coal fragments during liquefaction is an important process. As can be seen from Table:4, this increase is more pronounced for the reactions run under nitrogen than for the reactions run under hydrogen. The differences between the experiments done under nitrogen and under hydrogen suggest that hydrogen plays an important role during liquefaction even at reaction temperatures as low as $350^{\circ} \mathrm{C}$.

To further clarify this point, liquefaction of Illinois No. 6 whole coal was done at $350^{\circ} \mathrm{C}$ for $10 \mathrm{~min}$. in tetralin solvent under nitrogen and hydrogen atmosphere. The reaction products (prior to pyridine extraction) were subjected to elemental analysis. Results are collected in Table 5. Also included in Table 5 are the amounts of hydrogen consumed by coal from tetralin obtained by GC measurements of naphthalene produced. All data in the table are given as weight $\%$ based on daf coal. As can be seen from Table 5 , the $\mathrm{H} / \mathrm{C}$ ratio of the Iiquefaction products is increased compared with the starting coal and is higher for the reaction done under hydrogen. Reaction in hydrogen also gives higher yields of pyridine soluble products than the reaction done under nitrogen. on the other hand, less hydrogen is consumed from tetralin in the presence of hydrogen gas. Using the analyses in Table 5, we calculated the amount of hydrogen transferred to coal from a source different than tetralin. For the reaction done under nitrogen the calculation gives a negligible value of $0.08 \%$, while for the reaction done under hydrogen the calculation gives a value of $0.55 \%$. Thus hydrogen from $\mathrm{H}_{2}$ is indeed incorporated in coal at 
Table 5 .

Hydrogen balance of the liquefaction of Illinois No.6 coal $(2.00$ g) in the presence of tetralin $(4.00 \mathrm{~g})$ at $350^{\circ} \mathrm{C}$, for $10 \mathrm{~min}$. under nitrogen ( $1 \mathrm{~atm}$ ) or hydrogen (2000 psi).

\begin{tabular}{|c|c|c|c|c|c|c|c|}
\hline Entry & Atmosphere & Yield & Eleme & ital & al. & $\circ \mathrm{H}_{\text {tetralin }}$ & $\% \mathrm{H}$ other \\
\hline & & {$\left[\begin{array}{ll}\% & d a f\end{array}\right]$} & $\% \mathrm{C}$ & $\% \mathrm{H}$ & $\mathrm{H} / \mathrm{C}$ & & \\
\hline $1^{a}$ & - & - & 77.67 & 5.00 & 0.77 & - & - \\
\hline 2 & $\mathrm{~N}_{2}$ & 56.6 & 77.74 & 5.24 & 0.81 & 0.19 & 0.08 \\
\hline 3 & $\mathrm{H}_{2}$ & 63.3 & 79.03 & 5.45 & 0.83 & 0.11 & 0.55 \\
\hline
\end{tabular}

Analytical data. in the Table are given as $\%$ wt based on daf coal. a-elemental analysis of the substrate Illinois No.6 coal 
$350^{\circ} \mathrm{C}$.

Based on thermodynamic considerations it is not likely that $\mathrm{H}_{2}$ will compete with tetralin as a hydrogen source in radical reactions at $350^{\circ} \mathrm{C}$. This prompted us to look for alternate reaction pathways "allowed" for hydrogen at $350^{\circ} \mathrm{C}$. The most likely alternative seemed to be a 1,4 hydrogen addition to acene-like structures of coal. The hydroaromatics thus formed would in turn act as hydrogen shuttlers, transferring hydrogen to other parts of coal. If that mechanism was operative, the addition of anthracene to reaction mixture should enhance coal degradation processes under hydrogen atmosphere, while the addition of phenanthrene (not capable of undergoing 1,4 hydrogen addition) should not. This hypothesis seemed to be confirmed by results reported by other authors in similar processes. 14 To check the hypothesis, we studied the influence of additives such as anthracene and phenanthrene on the liquefaction yield and molecular weight distribution of the pyridine-soluble products. For both additives (10\% wt aid $50 \%$ wt based on the Illinois No.6 coal substrate) reactions were run with tetralin as a solvent, at $350^{\circ} \mathrm{C}$, for $10 \mathrm{~min}$ under nitrogen or hydrogen. The results are collected in Table 6 . The data show that phenanthrene is a better additive than anthracene. Thus our results do not confirm the proposed hydrogen transfer mechanism from molecular hydrogen to coal. At present we do not fully understand the mechanisms operative in the above coal transformations and further experiments in this area are underway. 


\section{Table 6.}

Iiquefaction results of Illinois No.6 coal $(2.00 \mathrm{~g})$ in the presence of titralin $(4.00 \mathrm{~g})$ and the additives $(0.20 \mathrm{~g}$ or $1.00 \mathrm{~g})$ at $350^{\circ} \mathrm{C}$ for $10 \mathrm{~min}$ under nitrogen ( $1 \mathrm{~atm}$ ) or hydrogen (2000 psi).

$$
\begin{gathered}
\text { Entry Atmosphere Additive }{ }^{a} \text { Yield } \\
{[\% \text { daf] }}
\end{gathered} \quad \begin{gathered}
\mathrm{H}_{\text {tetralin }} \\
\overline{\mathrm{M}}_{\mathrm{n}}
\end{gathered} \overline{\mathrm{M}}_{\mathrm{W}}
$$

$\begin{array}{lllllll}1 & \mathrm{~N}_{2} & - & 56.6 & 0.19 & 20100 & 92800 \\ 2 & \mathrm{H}_{2} & - & 65.3 & 0.11 & 22600 & 95200 \\ 3 & \mathrm{~N}_{2} & 10 \% \mathrm{~A} & 46.9 & 0.16 & 10500 & 55500 \\ 4 & \mathrm{H}_{2} & 10 \% \mathrm{~A} & 65.4 & 0.14 & 17200 & 78800 \\ 5 & \mathrm{~N}_{2} & 50 \% \mathrm{~A} & 50.6 & 0.16 & 13900 & 69700 \\ 6 & \mathrm{H}_{2} & 50 \% \mathrm{~A} & 69.5 & 0.13 & 18900 & 87600 \\ 7 & \mathrm{~N}_{2} & 10 \% \mathrm{P} & 58.1 & 0.17 & 6200 & 30500 \\ 8 & \mathrm{H}_{2} & 10 \% \mathrm{P} & 79.1 & 0.17 & 8800 & 34400 \\ 9 & \mathrm{~N}_{2} & 50 \% \mathrm{P} & 71.6 & 0.12 & 16300 & 80200 \\ 10 & \mathrm{H}_{2} & 50 \% \mathrm{P} & 82.2 & 0.11 & 18900 & 87500\end{array}$

a-additives are $\mathrm{A}$-anthracene, $\mathrm{P}$-phenanthrene 
Iiquefaction experiments were run with Illinois No. 6 coal and, separately, on its pyridine isoluble and soluble portions. Two questions are addressed: 1) Can the product molecular weight distributions obtained with the pyridine extract and residue be added to generate the molecular weight distribution of the whole coal? 2) Does removing the pyridine extract alter reactivity?

To avoid changes in molecular weight distributions during storage, liquefaction and extraction procedures were carefully planned. Illinois No. 6 was dried at $110^{\circ} \mathrm{C}$ under vacuum to constant weight and was stored under dry $\mathrm{N}_{2}$. It was soxhlet extracted with pyridine for one week. Both the insoluble and soluble portions were dried and stored in the same manner as the coal. Liquefaction experiments were carried out using three tubing bombs containing: 1) Illinois No. 6 coal; 2) its pyridine insoluble component; and 3 ) its pyridine soluble component, all under the same conditions (tetralin, 1 atm $\mathrm{N}_{2}, \operatorname{cold}, 400$ or $425^{\circ} \mathrm{C}$, 10 - $60 \mathrm{~min})$. Rapid heating was obtained by plunging the reactor into a preheated sand bath where it was shaken vertically at 150 200 cycles per minute and cooled in air after withdrawal from the sand bath. The products were Soxhlet extracted with pyridine under nitrogen atmosphere for $24 \mathrm{~h}$, then analyzed by GPC within 3 $h$ after terminating the extraction.

The peak areas of the GPC elution curves for Illinois No. 6 coal, its pyridine extract and residue were normalized to $100 \%$ (respectively, $S_{I L}, S_{P S}$, and $S_{P I}$ ). $S_{P I}$ and $S_{P S}$ were multiplied by the factors derived from the pyridine extraction yield of Illinois No. $6 \operatorname{coal}\left(C_{X}=0.31\right)$ and liquefaction yields $\left(C_{C I}\right.$ and $C_{P S}>$ 0.91 ), then added to each other to generate a theoretical molecular weight distribution for whole coal products as follows: 


$$
s_{C A L}=s_{P I}:\left(1-c_{X}\right) \cdot c_{P I}+s_{P S} \cdot c_{X} \cdot c_{P S}
$$

In Figure 10, the results obtained for liquefaction products at 400 and $425^{\circ} \mathrm{C}$ are shown as a function of time. The molecular weights were calibrated using standard polystyrene samples. When the reaction was terminated after $10 \mathrm{~min}$, the higher molecular weight regions of the calculated curve (dotted line) are larger than those observed (solid line). In the lower molecular region, these are reversed. The Illinois No. 6 whole coal is more reactive than its pyridine soluble and insoluble components reacted separately. Higher temperature and prolonged reaction time clearly decreased the discrepancy between calculated and observed curved. From these results, materials extracted from Illinois No. 6 coal seems to play an important role at the beginning of the liquefaction reaction. A small higher molecular weight peak was observed only in the calculated GPC curve at $425^{\circ} \mathrm{C}$ for $60 \mathrm{~min}$. Its origin must be retrogressive reactions. Those retrogressive reactions to produce larger molecules are suppressed in the liquefaction of Illinois No. 6 whole coal.

The role of the solvent extractable portions of coals on their thermal depolymerization has been discussed. The results we obtained here are an unequivocal demonstration of the deleterious effect of removing an extract. We will continue to investigate the liquefaction of Illinois No. 6 coal, especially at lower temperatures and shorter reaction times. Once the liquefaction yield is decreased and the network depolymerization process can be followed by GPC, the conventional kinetic approaches of polymer chemistry can be applied. 

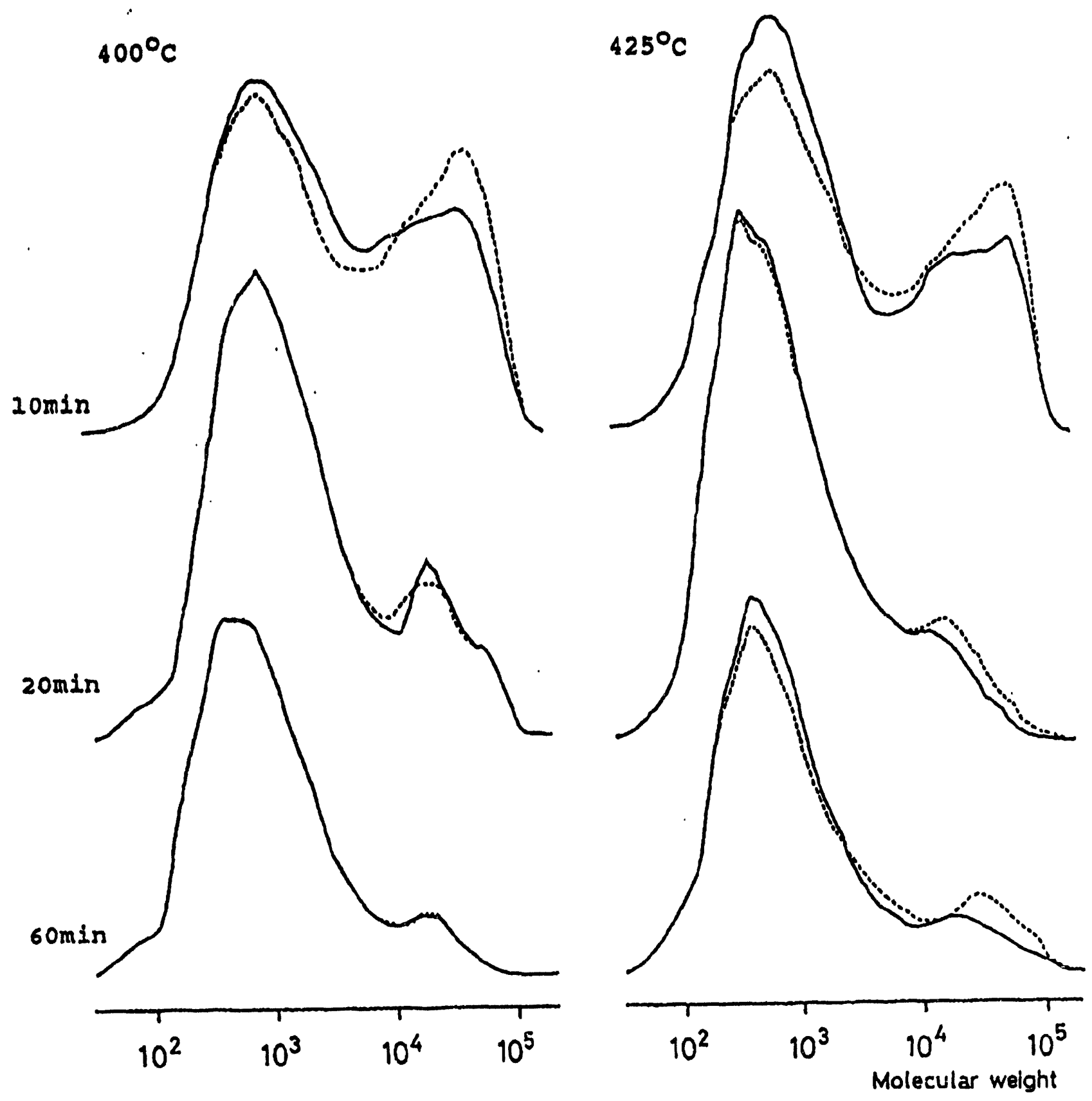

Figure 10. Comparison of observed and calculated molecular welght distribution for liquefaction products from Illinois No.6 coal

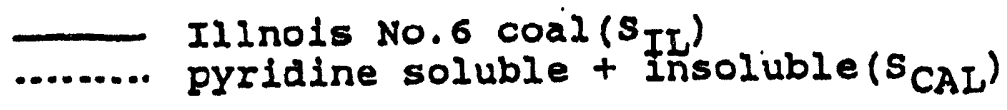


Conversion Product stability

We have observed that molecular weight distributions of coal liquid samples change during storage. In Figure 11, a typical weight distribution for a liquefaction product from Illinois No. 6 coal is shown. The solid line is for the freshly extracted (pyridine) sample. The dotted line is for the sample stored in a capped vial containing air for 10 dyas. Both samples completely passed a Millipore $0.2 \mu \mathrm{m}$ sample clarification filter. The increase in higher molecular weight materials indicates that polymerization or association of coal-derived molecules has occurred, possibly induced by oxidation.

Figure 12 shows the molecular weight change of pyridine extracts of Illinois No. 6 and Pittsburgh No. 8 coals during storage under air and under nitrogen. The changes in GPC curves were unexpectedly fast when stored in air. The high molecular weight peak increased with time, the highest end being around 500,000 of the polystyrene calibrated molecular weight. Coal liquefaction products with such high molecular weights are unbelievable, and promote the following simple question: Do high molecular weight materials really exist in coal extracts?

Lafleur and Nakagawa ${ }^{15}$ reported that the retention 


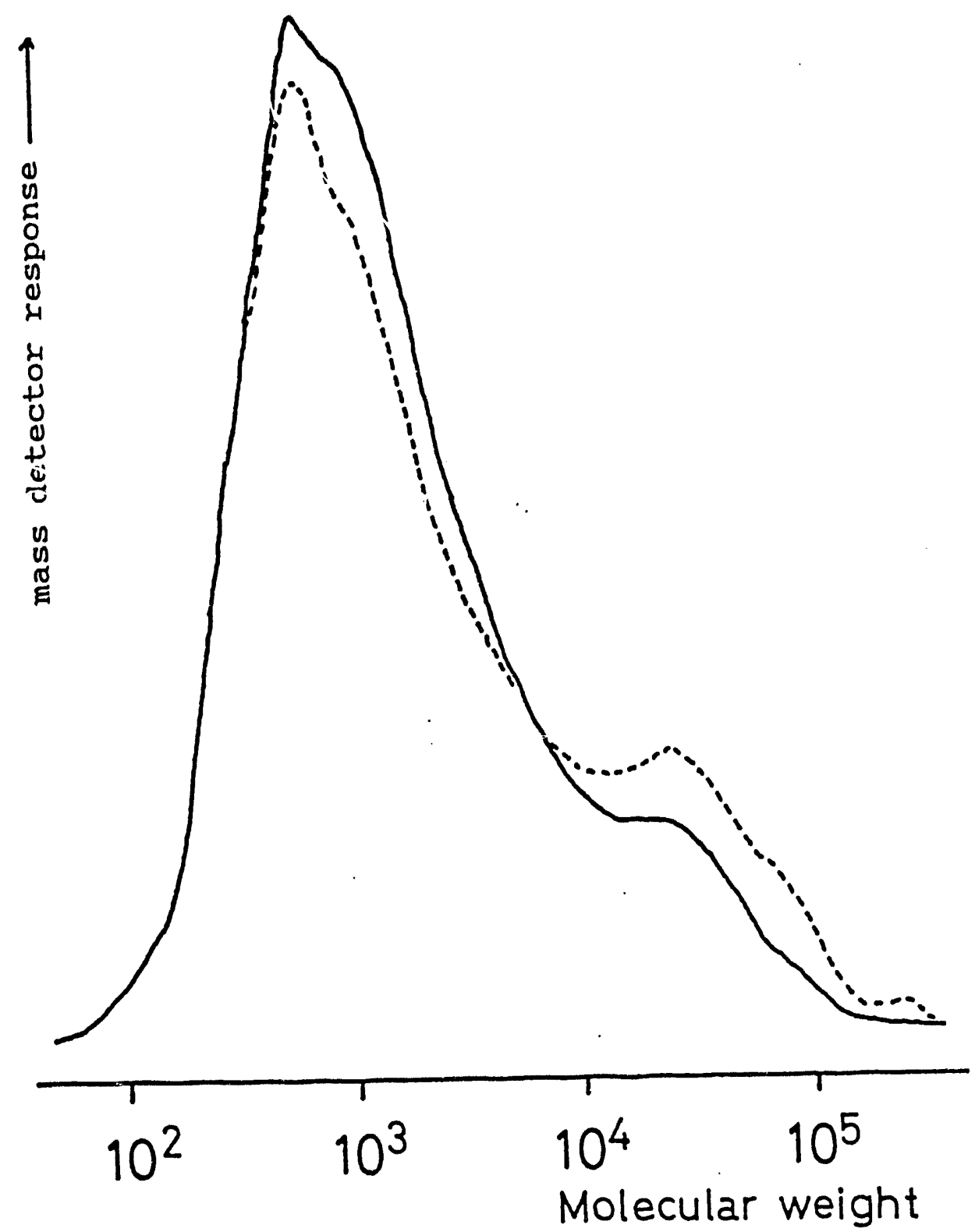

Figure 11. Change in molecular weight distribution of coal liquefaction product during storage

fresh sample
stored for 10 days 


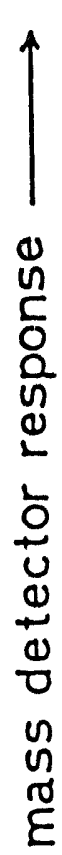

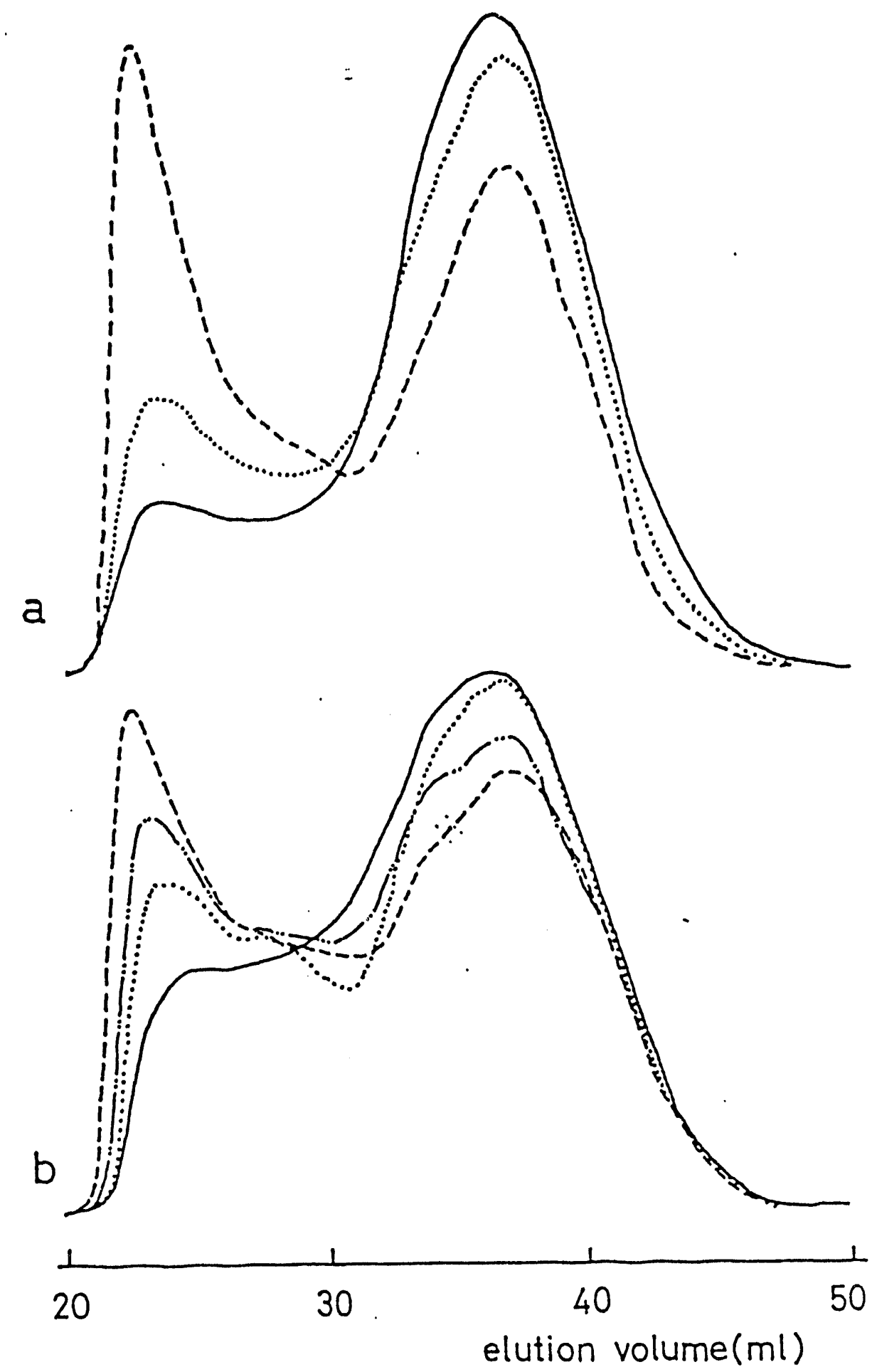

Figure 12. Changes in GPC curves of pyridine extracts during storage. a) Iliinois No.6 coal pyridine extracts; - fresh sample, .. after in under air, .-.- after 21 days under air, b) Pittsburgh No.8 coal pyridine extracts; - fresh sample, ........ after $2 \mathrm{~h}$ under air, ...- after 12 days under air, -... after 1 month under nitrogen atmosphere. 
volume of polynuclear aromatics containing oxygen functionality shows considerably shorter retention time in GPC than neutral polynuclear aromatic compounds of similar size in a highly polar solvent such as $\mathrm{N}$-methylpyrrolidinone as a mobile phase. The fact that materials having high polarity apparently produce high molecular weight peaks may explain our observation of the extremely high molecular weight peaks described above.

Reduction reactions using sodium borohydride are performed as follows. A pyridine solution of pyridine extracts of Illinois No. 6 and Pittsburgh No. 8 coals showing high molecular weight peaks were used as starting materials. Sodium borohydride is dissolved in pyridine (dried over KCI and degassed with nitrogen), then filtered with a 0.2 um sample clarification filter (Hillipore) to get saturated solution. A solution of $\mathrm{NaBH}_{4}$ was added to a stirred coal solution until the formation of $\mathrm{H}_{2}$ bubbles was completed. The reaction mixture was poured into water bubbled with $\mathrm{CO}_{2}$ to neutralize and was then Soxhlet extracted by water followed by pyridine. No residue was left in the extraction thimble after extraction with pyridine. Very similar results were obtained using Pittsburgh No. 8 coal.

The changes in the GPC chromatograms are shown in Figure 13 The areas of the chromatograms are normalized to $100 \%$ for convenient comparison. There seems to be very little change in the shape and area of the lower molecular weight peak centered at $38 \mathrm{mI}$ of elution volume after treatment with $\mathrm{NaBH}_{4}$. On the other hand, a sharp peak at the high molecular weight end disappeared 


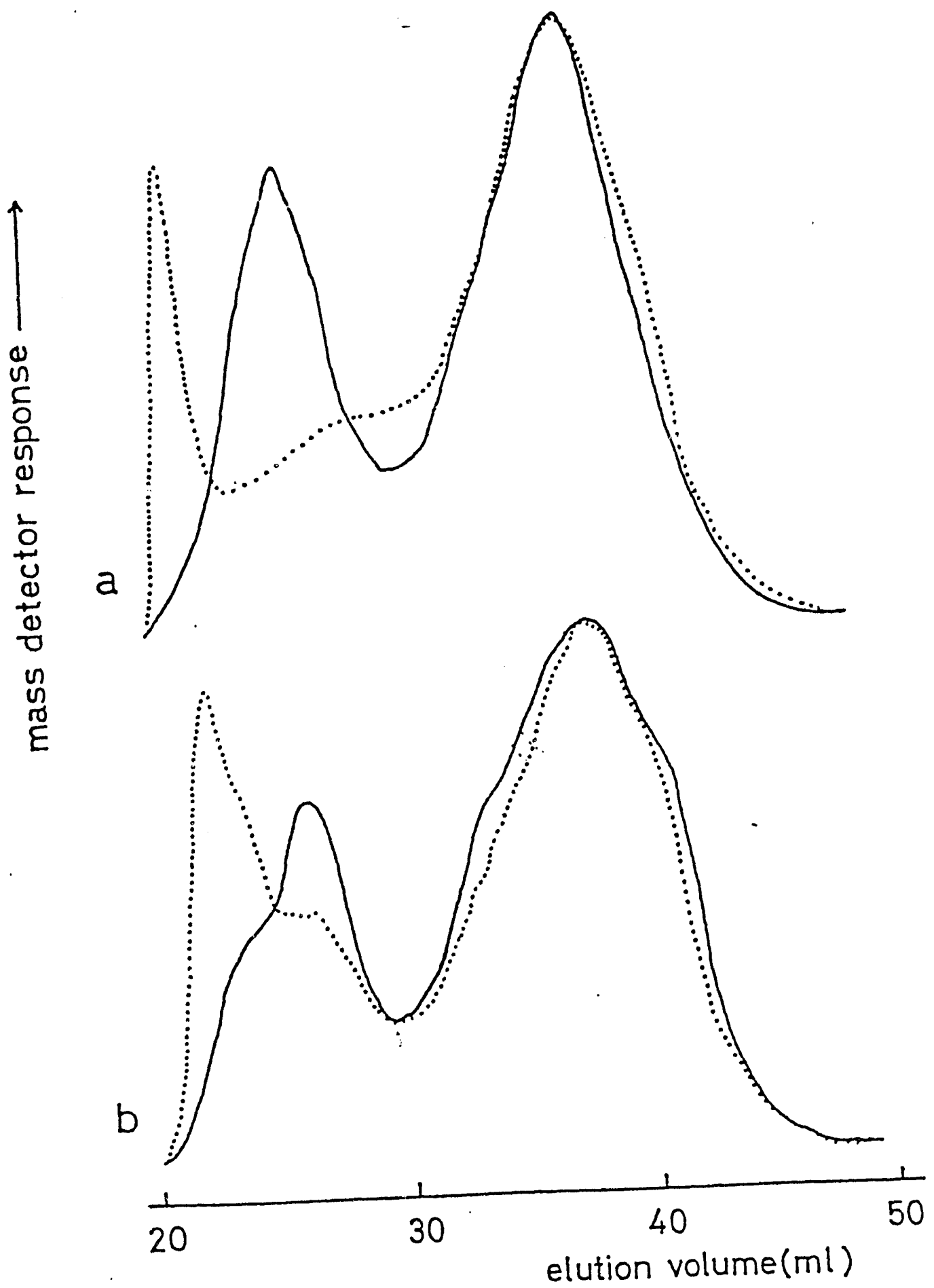

Figure 13. GPC elution curves of pyridine extracts of a) Illinois No.6 coal and b) Pittsburgh No.8 coal before (.......) and after $(-)$ reduction with sodium borohydride. 
volume. Since $\mathrm{NaBH}_{4}$ is a rather mild reagent and the reaction was conducted at room temperature, the reduction of $-\mathrm{C}=0$ sites in coal extracts to $-\mathrm{OH}$ is at least expected, ${ }^{16}$ but no bond breakage was expected. The results obtained here clearly indicate that the sharp peak observed in the very high molecular weight region (higher than $10^{5}$ ) does not reflect its molecular size. After hydrogenation using $\mathrm{NaBH}_{4}$, however, two peaks were observed and the molecular weight of the high end is still higher than estimated by us $^{3}$ and by other researchers. 17,18

The effect of reduction on size exclusion chromatograms of the coal liquid in polar solvent such as pyridine will be studied further using $\mathrm{LiAlH}_{4}$ as a hydrogenation reagent ${ }^{16}$ and using the methylation technique proposed by stock and coworkers." . We would like to emphasize that no fundamental investigation on coal depolymerization can be conducted without knowing the exact molecular weight of the depolymerized products.

Effect of Added Phenanthrene and Anthracene

In the present work, a series of Iiquefaction experiments was run using Illinois No.6 coal as the starting material. The influence of additives such as anthracene and phenanthrene on conversion to pyridine soluble products was studied. Reactions were run under nitrogen or hydrogen with tetralin as a solvent at $420^{\circ} \mathrm{C}$ for $3 \mathrm{~min}$. In another series of experiments, the influence of dihydroxybenzenes such as catechol and resorcinol was studied. Reactions were run under nitrogen or hydrogen, with tetralin as a solvent, at $350^{\circ} \mathrm{C}$ for $10 \mathrm{~min}$.

Illinois No.6 coal was dried at $110^{\circ} \mathrm{C}$ under vacuum to constant weight and stored under dry nitrogen. Iiquefaction experiments were carried out using tubing bombs. The tubing bombs 
contained coal, tetralin as a solvent, and the additive. Additives were dried and kept under nitrogen prior to reaction. Two reactions were run in parallel, one with 1 atm of nitrogen. The other was charged at room temperature with hydrogen such that the pressure was 2000 psi:at the reaction temperature. Rapid heating was obtained by plunging the reactors into a preheated sand bath. The bombs were shaken at 200-250 cycles per minute for a desired period of time. The reactors were air cooled after they were withdrawn from the sand bath. The products were removed from the tubing reactors and handled in a nitrogen-filled glove bag. They were soxhlet-extracted with pyridine under a nitrogen atmosphere until the solvent was clear. The reported yields of pyridine soluble products were based on the amount of the insoluble residue remaining after the soxhlet extraction. Pyridine extracts were analyzed by GPC and GC.

We investigated the possibility of concerted 1,4 hydrogen addition to various structures present in coal as a pathway for molecular hydrogen incorporation into coal during direct. Iiquefaction. The first coal structures targeted were acenes, for which a 1,4 addition of molecular hydrogen is a thermally allowed ${ }^{5}$ and thermodynamically favorable process. The hydroaromatics formed in a concerted process would in turn act as hydrogen donors in radical reactions transferring hydrogen to other parts of coal. We expected that addition of anthracene to the reaction mixture should enhance coal hydrogenation processes under a $\mathrm{H}_{2}$ atmosphere, while addition of phenanthrene (not capable of undergoing 1,4 hydrogen addition; 1,2 hydrogen addition being thermally forbidden) should not. 
We previously reported reactions of Illinois No.6 coal at $350^{\circ} \mathrm{C}$ for $10 \mathrm{~min}$ in tetralin under nitrogen and hydrogen atmospheres with the addition of anthracene or phenanthrene 6 . The data obtained did not give unambigous confirmation of the hypothesis, because both additives enhanced coal depolymerization processes.

In this report we present the data obtained for Illinois No. 6 coal conversion at a higher temperature $\left(420^{\circ} \mathrm{C}\right)$ for $3 \mathrm{~min}$ in tetralin under nitrogen or hydrogen and with added anthracene and phenanthrene. The results, together with control eperiments without additives and also without solvent, are collected in Table 1. Some molecular weight distribution data are missing due to the break-down of the instrument, but what we have permits some conclusions. First of all, the presence of $\mathrm{H}_{2}$ plays a significant role in coal depolymerization. In the control experiments in which coal was heated to $420^{\circ} \mathrm{C}$ for $3 \mathrm{~min}$ under nftrogen or hydrogen without solvent (entries 1 and 2 , Table 7 ) the yield of pyridine solubles almost doubled when $\mathrm{H}_{2}$ was present. Also, in all other reaction pairs, the yields of pyridine extractables were always higher for reactions done under hydrogen. This behaviour is well known . Entries 5-8 in Table 7 give results of Illinois No.6 coal conversion in the presence of added anthracene or phenanthrene. Comparison of the data clearly shows that at $420^{\circ} \mathrm{C}$ anthracene enhances conversion more than phenanthrene. This result suggests that at this higher temperature a 1,4 concerted hydrogen addition pathway may be operative. 
Table 7.

Iiquefaction results of Illinois No.6 coal $(2.00 \mathrm{~g})$ in the presence of tetralin $(4.00 \mathrm{~g})$ and the additives $(0.20 \mathrm{~g})$ at $420^{\circ} \mathrm{C}$ for $3 \mathrm{~min}$ under nitrogen (1 atm) or hydrogen (2000 psi).

Entry Atmosphere Additive ${ }^{a}$ Yield ${ }^{b} \mathrm{H}_{\text {tetralin }} \quad \overline{\mathrm{M}}_{\Omega} \quad \overline{\mathrm{M}}_{\mathrm{W}}$ [\%daf] [\%daf]

\begin{tabular}{lllllll}
$1^{\mathrm{C}}$ & $\mathrm{N}_{2}$ & - & - & 39 & - & \multicolumn{2}{c}{ no data } \\
$2^{\mathrm{C}}$ & $\mathrm{H}_{2}$ & - & 77 & - & \multicolumn{2}{c}{ no data } \\
3 & $: \mathrm{N}_{2}$ & - & 73 & 0.20 & 8200 & 39400 \\
4 & $\mathrm{H}_{2}$ & - & 86 & 0.15 & 14800 & 54800 \\
5 & $: \mathrm{N}_{2}$ & $\mathrm{~A}$ & 88 & 0.21 & 7900 & 40000 \\
6 & $\mathrm{H}_{2}$ & $\mathrm{~A}$ & 92 & 0.19 & 9700 & 46300 \\
7 & $\mathrm{~N}_{2}$ & $\mathrm{P}$ & 78 & 0.38 & no data \\
8 & $\mathrm{H}_{2}$ & $\mathrm{P}$ & 86 & 0.39 & no data
\end{tabular}
a - additives are A-anthracene, P-phenanthrene
b - as pyridine soluble material
c - reaction run without tetralin 
In another series of experiments, we examined the effect of dihydroxybenzene structures on coal conversion. Some molecules having this structural group can undergo concerted 1,4 hyarogen addition. Resorcinol and hydroquinone may undergo the reactions below. The reactions are both thermodynamically favorable.<smiles>Oc1cccc(O)c1</smiles><smiles>CCCCC</smiles><smiles>OC1=CCC=C(O)C1</smiles><smiles>CCCCCCCC</smiles><smiles>O=C1CCCC(=O)C1</smiles>
$\Delta \mathrm{H}=-12.15 \mathrm{kcal} / \mathrm{mol}$<smiles>Oc1ccc(O)cc1</smiles><smiles>CCCC</smiles><smiles>OC1=CCC(O)=CC1</smiles><smiles>CCCCC</smiles><smiles>O=C1CCC(=O)CC1</smiles>

$\Delta \mathrm{H}--12.40 \mathrm{kcal} / \mathrm{mol}$

Resorcinol and hydroquinone were used as additives during Illinois No.6 coal. Iiquefaction at $350^{\circ} \mathrm{C}$ for $10 \mathrm{~min}$ with tetralin as a solvent under nitrogen or hydrogen atmosphere and the results are collected in Table 2 . Both additives enhance coal dopolymerization processes (measured as yield of pyridine solubles) under hydrogen atmosphere (16\% enhancement for resorcinol; 11\% enhancement for hydroquinone) more than occurred without either additive ( $9 \%$ enhancement). The differences are too small to be taken as evidence that dihydroxybenzene structures play a significant role in hydrogen transfer. Directionally they are consistent with occurrence of a $1,4 \mathrm{H}_{2}$ addition. 
Table 8.

Iiquefaction results of Illinois No.6 coal $(2.00 \mathrm{~g})$ in the presence of tetralin $\left(4.00^{\circ} \mathrm{g}\right)$ and the additive $(0.20 \mathrm{~g})$ at $350^{\circ} \mathrm{C}$ for $10 \mathrm{~min}$ under nitrogen ( $1 \mathrm{~atm}$ ) or hydrogen (2000 psi):

Entry Atmosphere Additive ${ }^{a}$. Yield ${ }^{b} \quad \% H_{\text {tetralin }} \bar{M}_{n} \quad \bar{M}_{W}$ [\%daf] [\%daf]

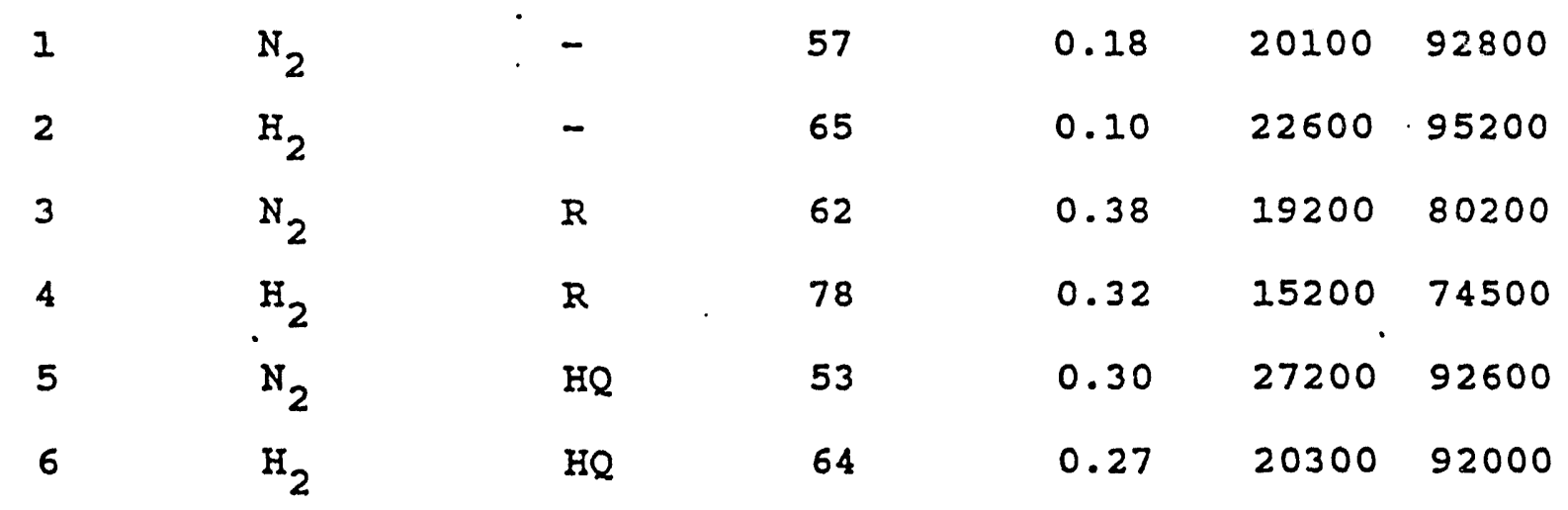

\footnotetext{
a - additives are $R$ - resorcinol, HQ - hydroquinone

b - as pyridine soluble material
} 


\section{Conversion of Macerals}

We have used our approach to study the conversion of individual macerals using samples provided by Dr. Birbal Chawla from the Kentucky Energy Research Center. Eastern Kentucky coal from the lower Elkhorn seam was separated and the liptinite, vitrinite, and inertinite macerals were isolated. ${ }^{21-23}$ The original coal and the three macerals were liquefied at $427^{\circ} \mathrm{C}$ in tetralin with a residence time of 15 minutes under 800 psig hydrogen (cold). Liquefaction products were solvent fractionated to oils (pentane soluble), asphaltenes (benzene soluble, pentane. insoluble), and preasphaltenes (pyridine soluble, benzene insoluble).

Molecular weight distributions of the twelve samples were measured by GPC. Molecular weight calibration used commercially available standard polystyrenes. Although absolute molecular weights are not obtained because of calibration errors, we believe it is reasonable to compare our $\bar{M}_{n}$ and $\vec{M}_{w}$ values as long as the measurements were done under the same conditions.

Results are summarized, together with liquefaction yields, in Table 9. The total conversion of liptinite is higher than that of the parent coal. Inertinite gave the lowest total conversion, as expected. The product distributions from liptinite are similar to that of the parent coal. The oil fraction from inertinite, however, seems to be higher than those from other materials when considered as a percent of the total conversion (27.5\% for the parent coal, $37.2 \%$ for inertinite, $28.2 \%$ for vitrinite, and $24.6 \%$ for liptinite, respectively). The maceral conversion data is as expected. 


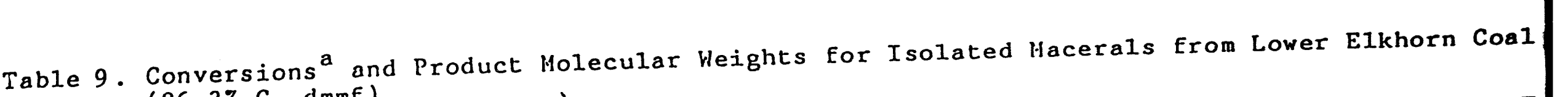

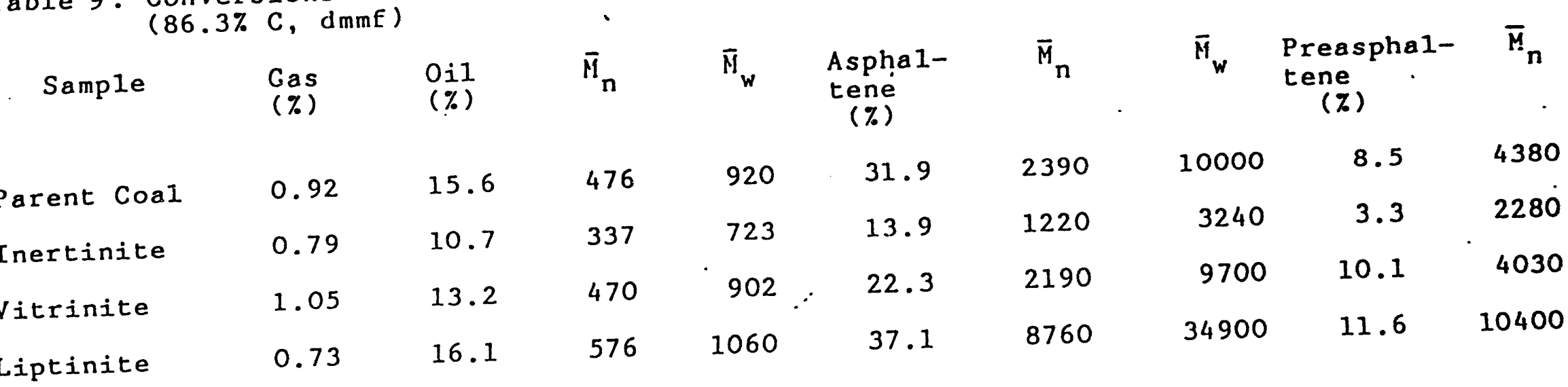

${ }^{\text {awt. } \% \text { daf coal }}$ 
The molecular weight distributions of the products include some surprises; most notably, the low molecular weights of the inertinite products. Similar molecular weight distribution profiles for oil, asphaltene, and preasphaltene from the parent coal and from vitrinite were observed. Fractions obtained from liptinite gave slightly higher molecular weights than those from the parent coal and vitrinite. The molecular weights of liquefaction products from inertinite were considerably lower, those of the asphaltenes and preasphaltenes being only half of those for the parent coal and vitrinite. Judging from the molecular weights, the inertinite fraction is the most reactive, followed by vitrinite and then liptinite. This trend in the molecular weight occurs in all of the fractions.

Jnertinite is thought to consist of condensed and crosslinked structures. Products having lower molecular weights and narrower molecular weight distributions were obtained from inertinite at lower conversion levels. This is not understood.

\section{${ }^{252}$ Cf Plasma Desorption Mass Spectrometry Molecular Weight Distributions}

Molecular weight determination is normally one of the first steps in charcterizing an unknown substance. The techniques in common use in coal chemistry are vapor pressure osmometry (VPO) and gel permeation chromatography (GPC). Both have well known disadvantages..$^{24}$ We are attemting to use cf-252 plasma desorption mass spectrometry (PDMS) to measure the molecular weight distribution of coal extracts and liquefaction products in order to use these data for kinetic analysis. 
Macfarlane and co-workers pioneered the use of cf-252 PDMS to determine molecular weights of large biological materials. 25 Ṕlasma desorption mass spectrometry utilizes a radioactive $c f-252$ source to volatize and ionize molecules without causing fragmentation. The ionized molecules subsequently are analyzed using the time-of-flight technique. ${ }^{26}$ The technique has been proven to be an effective method for determining molecular weights of biological molecules, such as proteins, having molecular weights up to 25000 amu. 26-28

In this period, we attempted to measure the molecular weight distribution of Illinois \#6 and Rawhide extracts dissolved in pyridine by PDMS using a Bioion-20 time-of-flight spectrometer. We employed a $15 \mathrm{kV}$ acceleration voltage, a $14 \mathrm{~cm}$ flight tube length, and an ion source containing $20 \mu \mathrm{ci}$ of $\mathrm{cf-252}$ emitting simultaneously two fragments at a rate of 2000 events/s. One of the fission fragments is detected to provide a start pulse, while the other emitted in the opposite direction is used to ionize and volatize the sample. The ionized sample is detected and provides a stop pulse. The flight time is the differece between the start and stop pulses. This technique has a maximum time resolution of Ins/channel and acquires up to 64 ions for each deposition event. All the spectra were acquired to a preset count $6 \times 10^{6}$ primary ion events. Diluted samples $(1-10 \mu \mathrm{g} / \mu \mathrm{l})$ of coal extracts dissolved in pyridine were electrosprayed under nitrogen, onto thin aluminum foil in order to obtain a thin homogenous coverage. A pyridine background spectrum was obtained in a similar manner. 


\section{The mass spectra obtained from the extracts are}

considerably more complicated than those obtained from biological materials. Therefore, we developed a software package that can be executed with any IBM compatable PC to determine the number average and weight average molecular weights. In addition, this software package allows us to subtract the backgroud which comes from solvent and mylar. Figure 14 shows the liquefaction product obtained directly from the mass spectrometer and the same data using our newly developed software with the background subtraction. The spectrometer software also adds counts from surrounding channels to the counted channel to enhance the signalto-noise ratio. This is undesirable for the determination of molecular weight distribution and has been removed from our data analysis.

In order to test the reproducibility of this system, we obtained the mass spectrum of Rawhide coal extract five times and each spectrum has been subtracted from the first. If the system is reproducible, each subtraction should show a zero baseline. Figure 15 shows the difference spectra. We observed a tendency towards increasingly negative broad peaks in the region between 2000-6000 ns with each increasing run number. This may be due to the loss of a small amount of material from the surface in each run. 


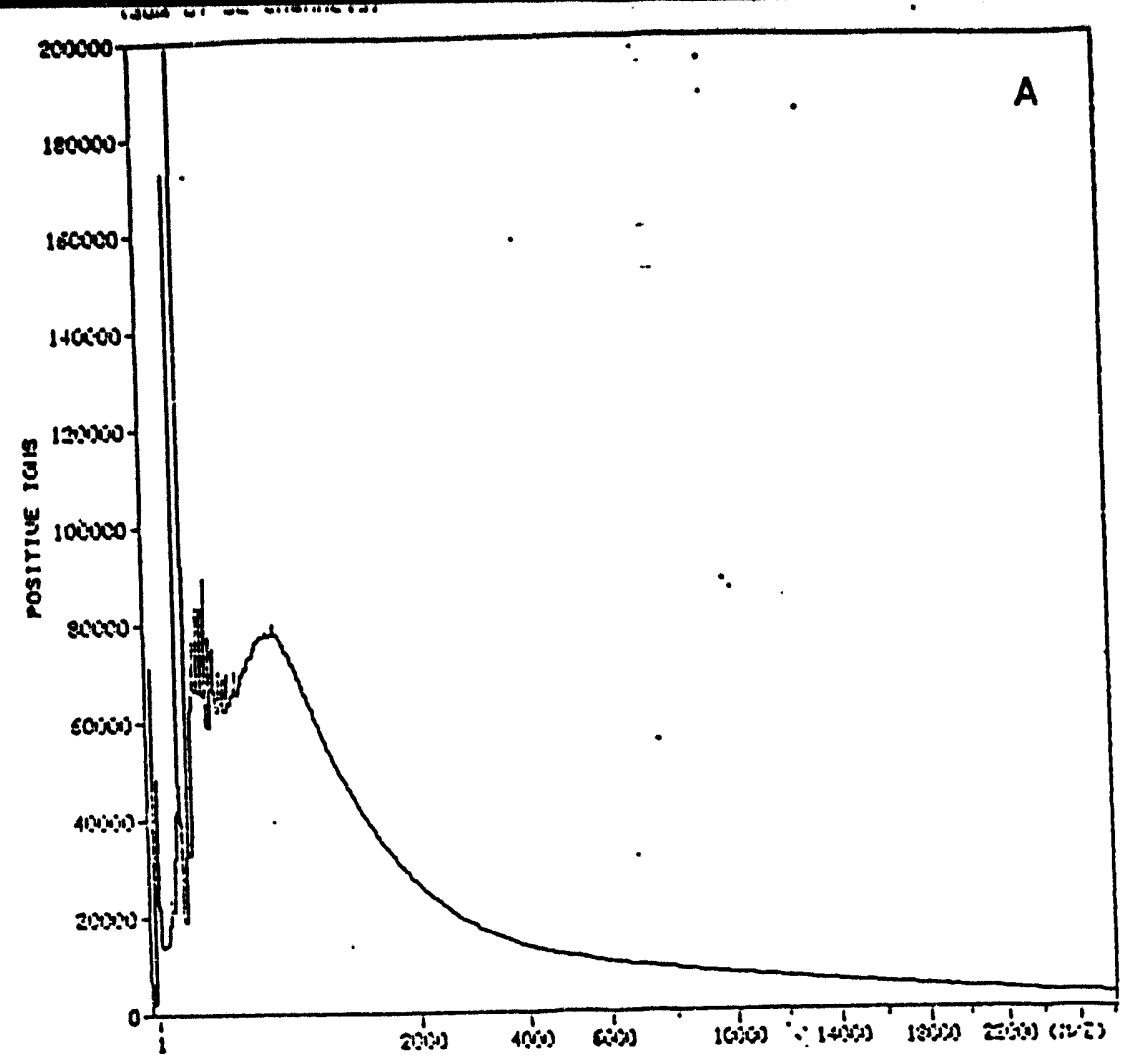

Figure 14 Mass spectra of a 11quetaction product.

A) obtained from mass spectrometry

B) obtạịned firom șptwậe 

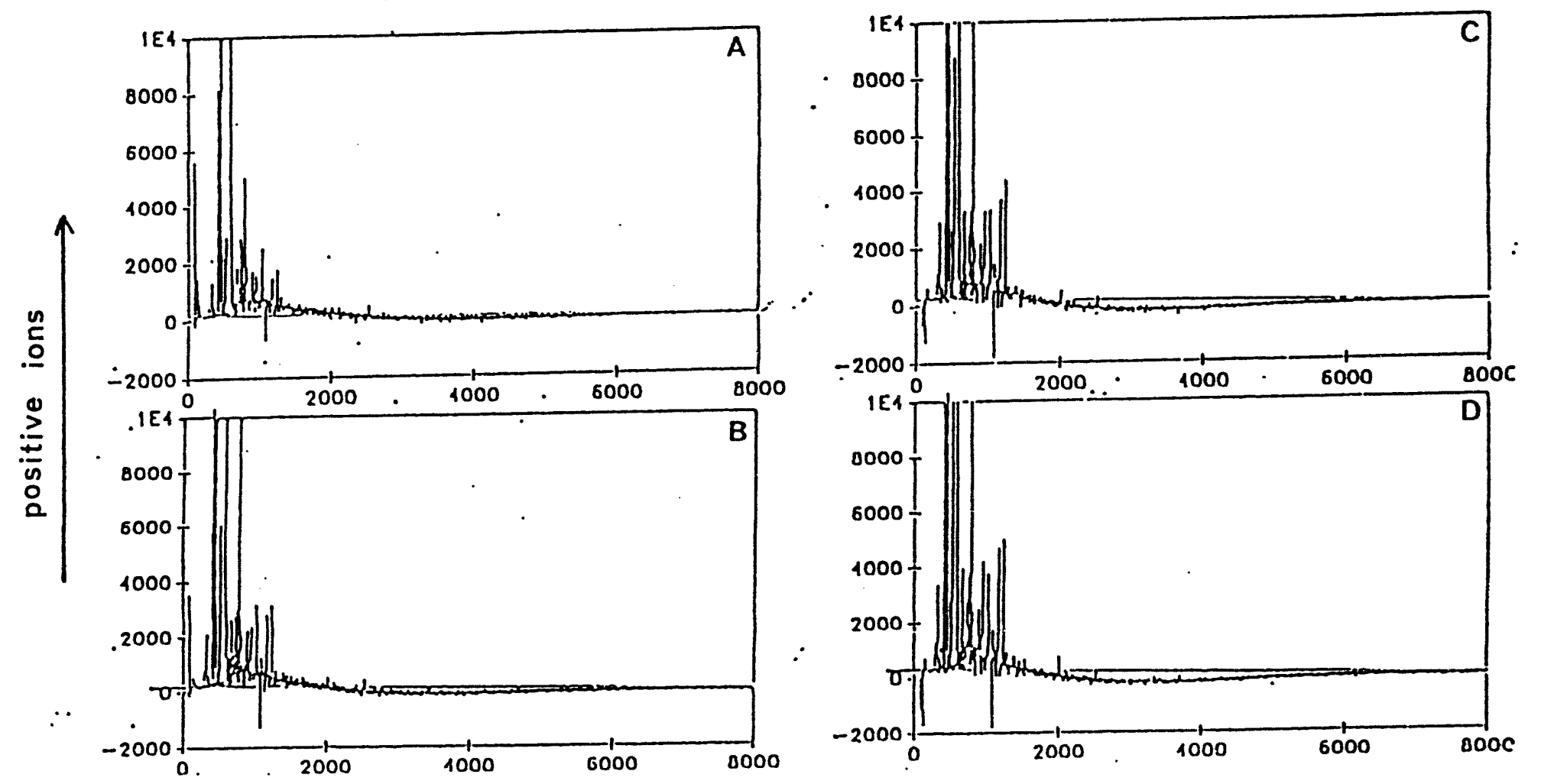

time (ns)

Figure 15 Difference mass spectra of Rawhide extract.
A) Run 2 - Run 1
C) Run 4 - Run 1
B) Run 3 - Run 1
D) Run 5 - Run 1 
1. Gorin, E. in "Chemistry of Coal Utilization", 2nd Suppl. Vol., M. A. Elliott, Ed., John Wiley, New York, 1981.

2. Albert, S. B. and Wolk, R. H. in "Chemistry of Coal Utilization", 2nd Suppl. Vol., M. A. Elliott, Ed., John Wiley, New York, 1981.

3. Larsen, J. W. and Wei, Y. C. Energy \& Fuels, 1988, 2, 344 .

4. Flory, P. J., "principles of Polymer Chemistry", Cornell University Press, Ithaca, New York, 1953.

5. Yan, J. F., Macromolecules, 1981, 14, 1438.

6. Pullen, J. R., "Solvent Extraction of coal", Coal Science, Vol. 2, Academic Press, New York, 1983:

7. Yan, J. F. and Johnson, D. C. J. Appli. Polym. SCi., $1981,26,1623$.

8. Yan, J. F. and Johnson D. C. I. Agri. Food Chem., 1980, 28,850 .

9. "Polymeric structure of spruce Lignin", Abstract, Science, Vol. 170, 170 (1970).

10. Buchanan, D. H., Warfel, L. C., Bailey, S., and Lucas, D. Energy \& Fuels, 1988, 2, 32 .

11. Yan, J. F., Macromolecules, 1981, 14, 1438.

12. Krishen, A., and Tucker, R.G. Anal. Chem. 1977, 69, 898 .

13. Lafleur, A. L. and Nakagawa, Y. Fuel, 1989, 68, 741. 
14. Kwon, K., Fuel 1985, 64, 747; Fatamura, S., Koyanag1, S1, Kamiya, Y., Euel, 1988, 67, 1436.

15. Lafleur, A.L. and Nakagawa, Y. Euel, 1989, 68, 741.

16. Hualicky, M., "Reduction in Organic Chemistry", Halsted Press, 1984.

17. Unger, P. E. and suuberg, E.M., Euel, 1984, 63, 606.

18. Wong, J. L., "Coal science and Chemistry", A. Volborth, Ed., Elsevier, 1987, p. 461.

19. Ettinger, M., Nardin, R., Mahasay, S. Ray and stock, L. M. I. Org. Chem., 1986, 51, 2480.

20. Utz, B. R., Appell, H. R., Blaustein, B. D., Euel, $1986,65,1085$.

21. Dyrkacz, G. R. and Horwitz, E. P., Euel, 1982, 62, 3.

22. Dyrkacz, G. R., Bloomquist, C. A. A., Horwitz, E.P., Seq. Sci. Tech. 1981, 16, 1571.

23. Dyrkacz, G. R., Fuel, 1984, 63, 1367.

24. Storm, D. A., Decanio, S. J., Fuel, $1990,69,735$.

25. Macfarlane, R. D. and Torgerson, D. G, Science, 1976, 192, 920 .

26. Cotter, R. J. Anal. Chem., 1988, 60, 781A.

27. Sundquist, B. Roepstorfe, P., and Folman, J., science, $1984,226,669$.

28. Alai, M., Demirev, P., and Cotter, R. J., Anal. Chem. $1986,58,1303$. 

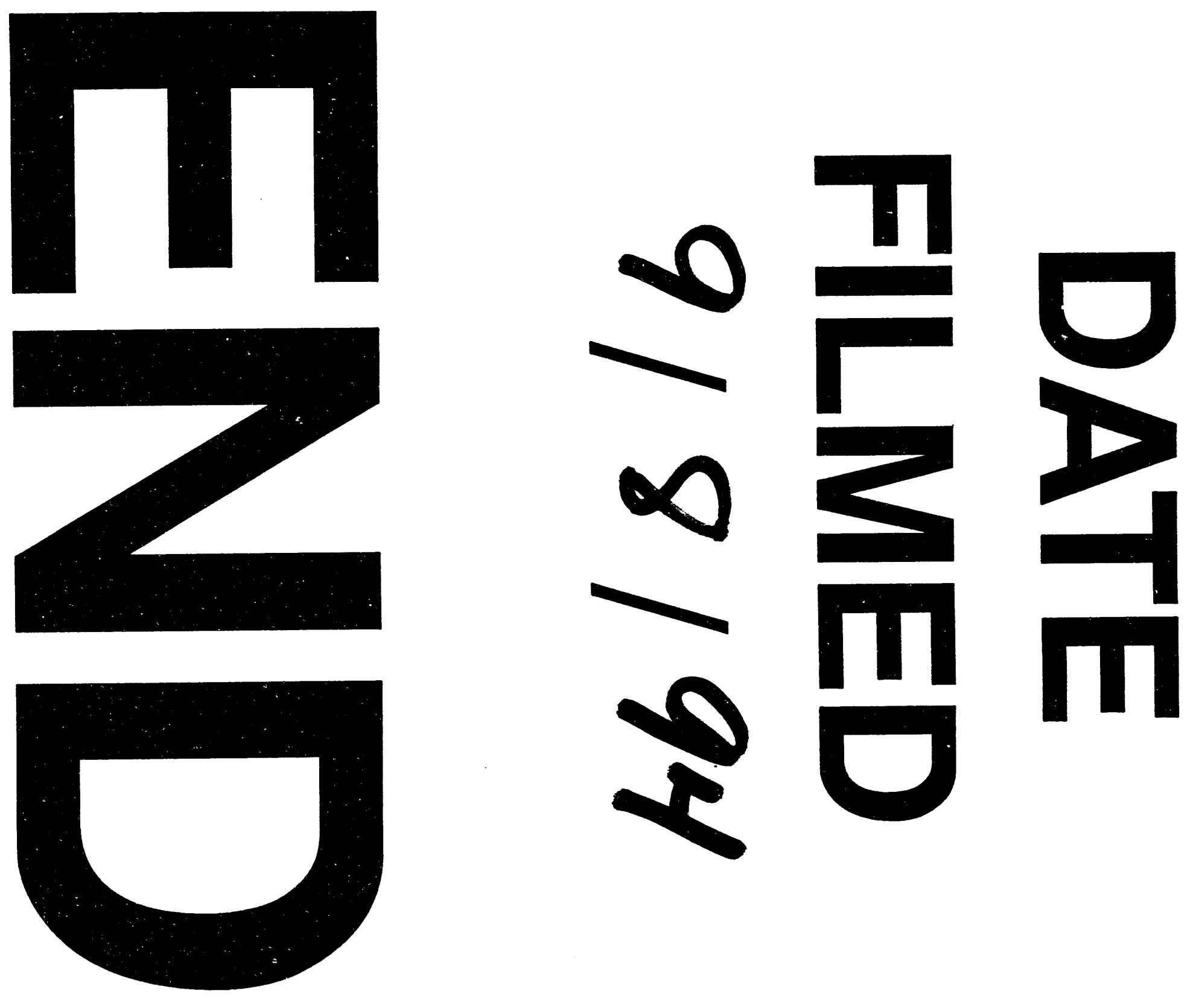


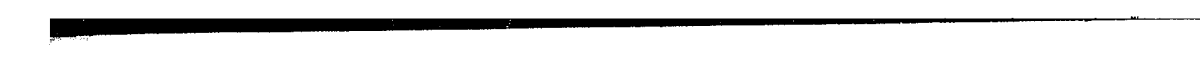

